\title{
Discovery of Potent Peptidomimetic Antagonists for Heterochromatin Protein 1 (HP1) Family Proteins
}

Kelsey N. Lamb, ${ }^{\dagger \#}$ Sarah N. Dishman,,$^{\dagger}$ Jarod M. Waybright,${ }^{\dagger}{ }^{\Psi}$ Isabelle A. Engelberg,,$^{\dagger}$ Justin M.

Rectenwald,$^{\dagger \perp}$ Jacqueline L. Norris-Drouin,,$^{\dagger}$ Stephanie H. Cholensky, ${ }^{\dagger \Sigma}$ Kenneth H. Pearce ${ }^{\dagger}$

Lindsey I. James, ${ }^{\dagger}$ Stephen V. Frye $e^{\dagger *}$

Center for Integrative Chemical Biology and Drug Discovery, Division of Chemical Biology and Medicinal Chemistry, UNC Eshelman School of Pharmacy, University of North Carolina at Chapel Hill, Chapel Hill, NC, 27599, USA

\section{Contents of SI}

Figure S1. OBOC Library Screening Cascade. On-bead screening cascade for the two CBX5 sub-libraries, demonstrating the order of soluble competitor and cross-screening steps.

Figure S2. ITC Analysis of OBOC Library Re-Synthesized Hits and Similar Analog with CBX5. Chemical structures, affinities, and ITC curves for closely related analogs, UNC5154 (left), UNC5156 (midle) and UNC5191 (right) as in Figure 2. Data is presented as one individual replicate for UNC154 and UNC5156 and mean \pm SD of two individual replicates for UNC5191.

Figure S3. ITC Analysis of UNC6384 and UNC6392 with CBX5. Chemical structures, affinities, and ITC curves for closely related analogs, UNC6384 (left) and UNC6392 (right). Data is representative of one individual replicate.

Figure S4. Representative ITC Curve of UNC7047 with CBX5. Data is representative of three separate ITC experiments with CBX5 protein and UNC7047 ligand.

Figure S5. Representative ITC Curves of UNC7560 with Individual Chromodomains. Data is representative of two separate ITC experiments with chromodomain proteins and UNC7560 ligand.

Figure S6. TR-FRET Curves of UNC7560 with Individual Chromodomains. Data is presented as mean $\pm \mathrm{SD}$ of three separate TR-FRET experiments with chromodomains and UNC7560 ligand. 
Figure S7. ITC Curves of UNC7560 with MPP8. Individual ITC curves of MPP8 protein and UNC7560 ligand, demonstrating that MPP8 weakly binds UNC7560 by ITC.

Figure S8. Uncropped western blots for individual proteins. For all blots, Lane $1=$ BioRad Precision Plus Protein Dual Color Standards (\#1610374), Lane 2= HE293T Lysate Input, Lane $3=$ UNC7565 pulldown, and Lane 4= UNC7565 pulldown with UNC7560 soluble competitor competition. Western blots shown are representative of two replicate experiments.

Supplementary Scheme I. Synthesis of Peptide Intermediates and UNC7560

Supplementary Scheme II. Synthesis of Carboxylic Acid Derivative, UNC7564, and Biotinylated Derivative, UNC7565

Figure S9. LCMS Chromatograms of Selected Compounds

Figure S10. ${ }^{1} \mathrm{H}$ NMR Spectra of Selected Compounds as TFA Salts

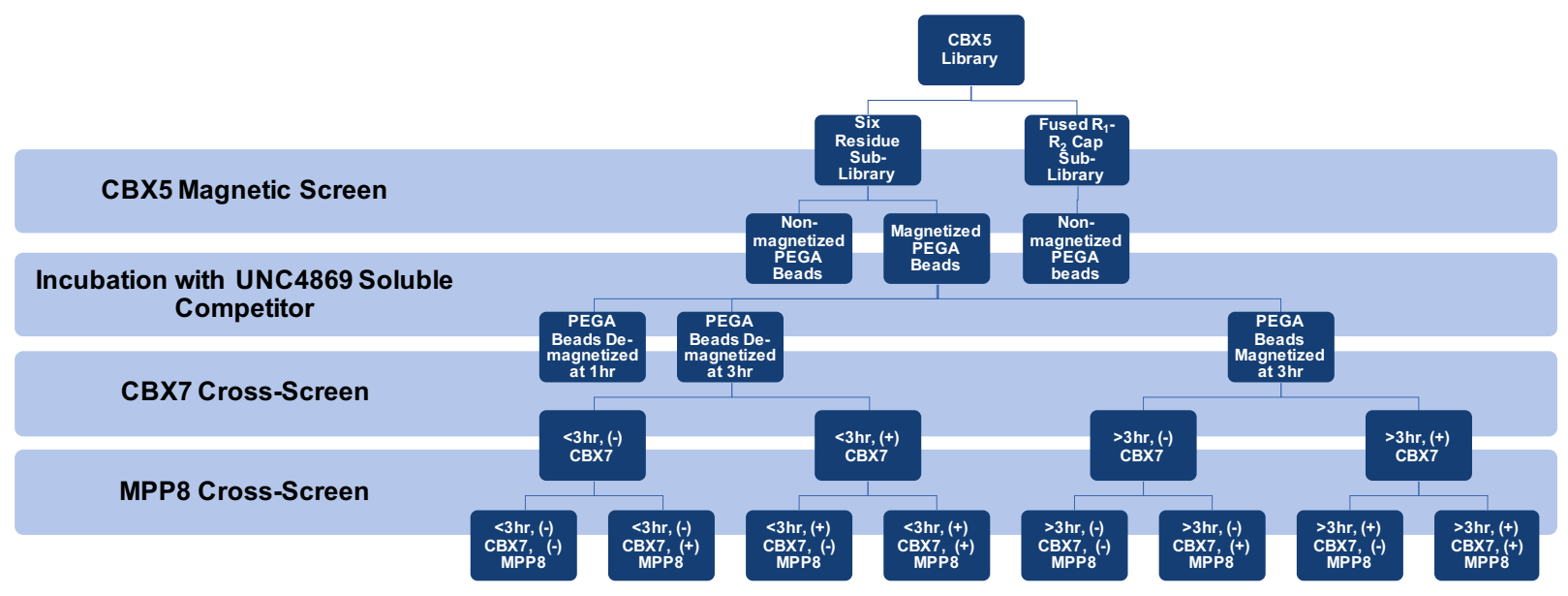

Figure S1. OBOC Library Screening Cascade. On-bead screening cascade for the two CBX5 sub-libraries, demonstrating the order of soluble competitor and cross-screening steps. 


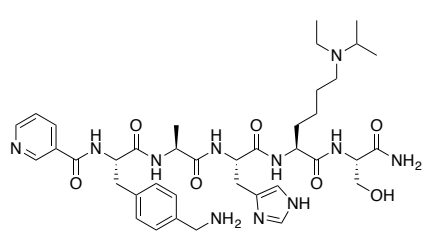

UNC5154

$\mathrm{CBX}_{5} \mathrm{~K}_{\mathrm{d}}(\mathrm{ITC})=4.95 \mu \mathrm{M}$

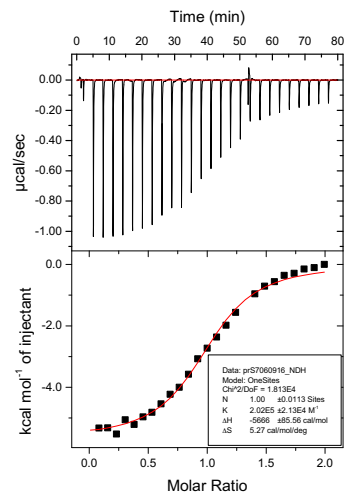

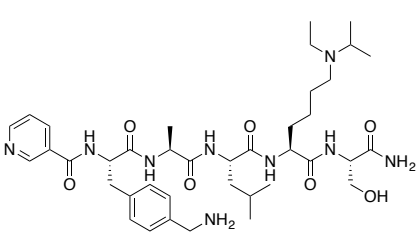

UNC5156

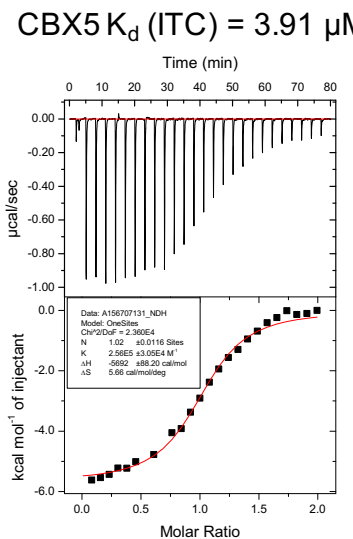

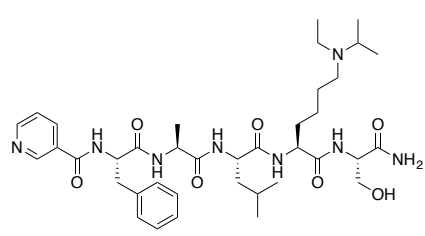

UNC5191

CBX5 $\mathrm{K}_{\mathrm{d}}(\mathrm{ITC})=6.93 \pm 0.82 \mu \mathrm{M}$

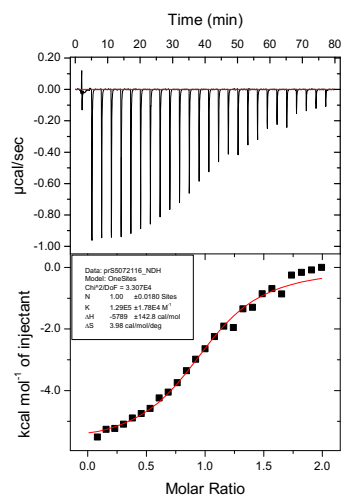

Figure S2. ITC Analysis of OBOC Library Re-Synthesized Hits and Similar Analog with CBX5. Chemical structures, affinities, and ITC curves for closely related analogs, UNC5154 (left), UNC5156 (midle) and UNC5191 (right) as in Figure 2. Data is presented as one individual replicate for UNC154 and UNC5156 and mean \pm SD of two individual replicates for UNC5191.

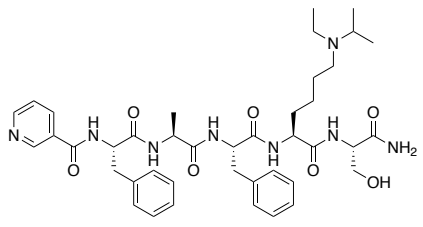

UNC6384

$\mathrm{CBX} \mathrm{K}_{\mathrm{d}}(\mathrm{ITC})=3.38 \mu \mathrm{M}$

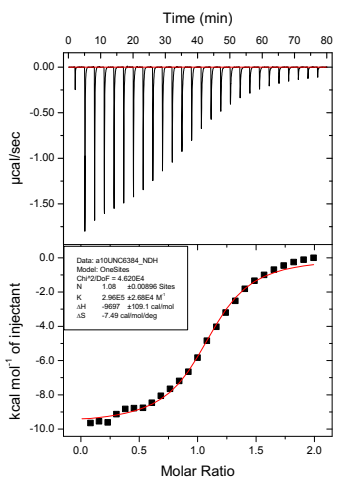

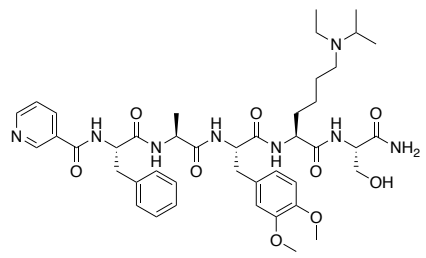

UNC6392

CBX5 $K_{d}(I T C)=1.27 \mu M$

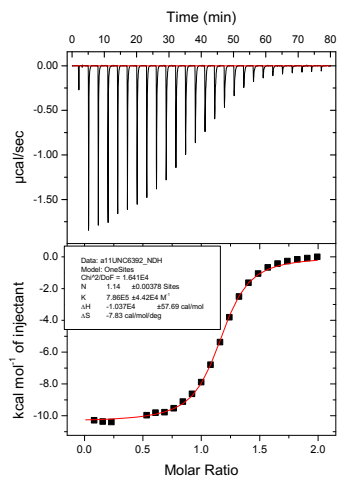

Figure S3. ITC Analysis of UNC6384 and UNC6392 with CBX5. Chemical structures, affinities, and ITC curves for closely related analogs, UNC6384 (left) and UNC6392 (right). Data is representative of one individual replicate. 


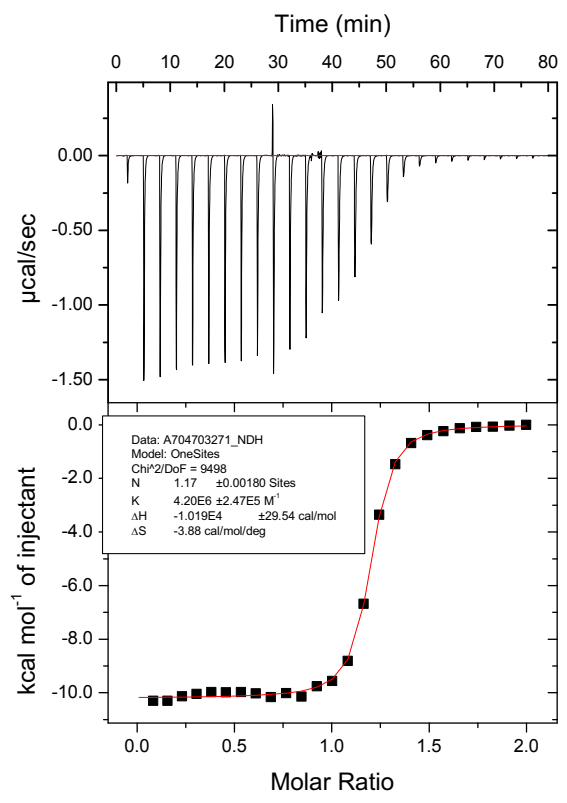

Figure S4. Representative ITC Curve of UNC7047 with CBX5. Data is representative of three separate ITC experiments with CBX5 protein and UNC7047 ligand. 

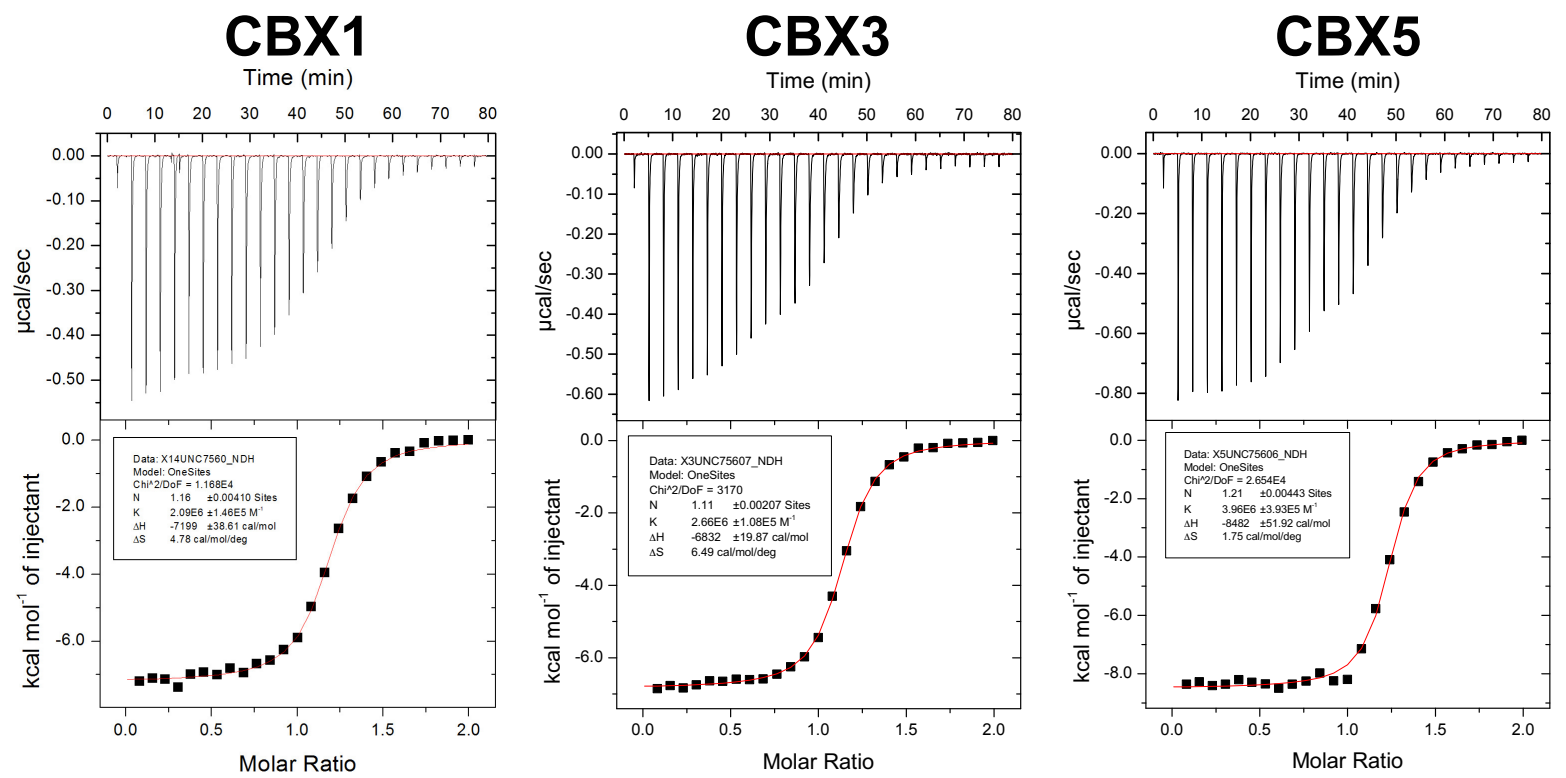

CBX7

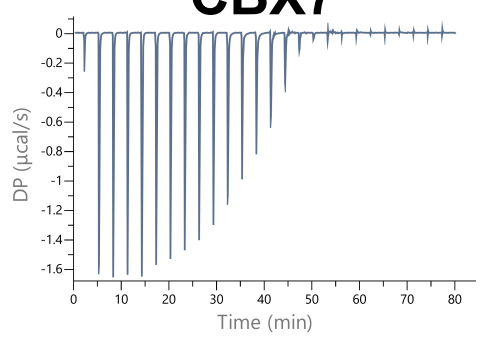

CDYL2
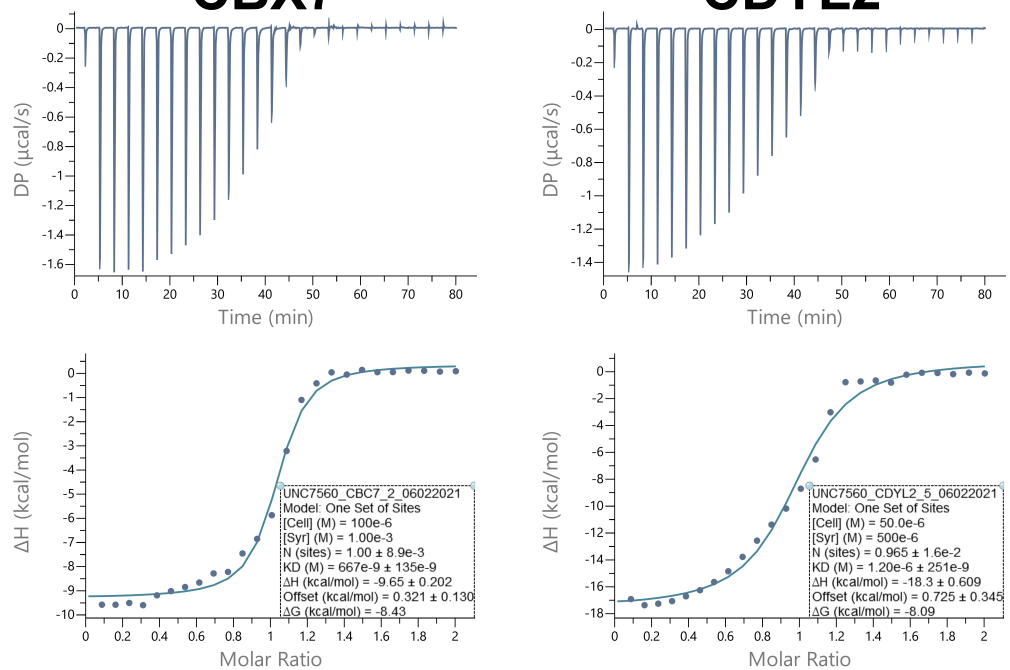

Figure S5. Representative ITC Curves of UNC7560 with Individual Chromodomains. Data is representative of two separate ITC experiments with chromodomain proteins and UNC7560 ligand. 


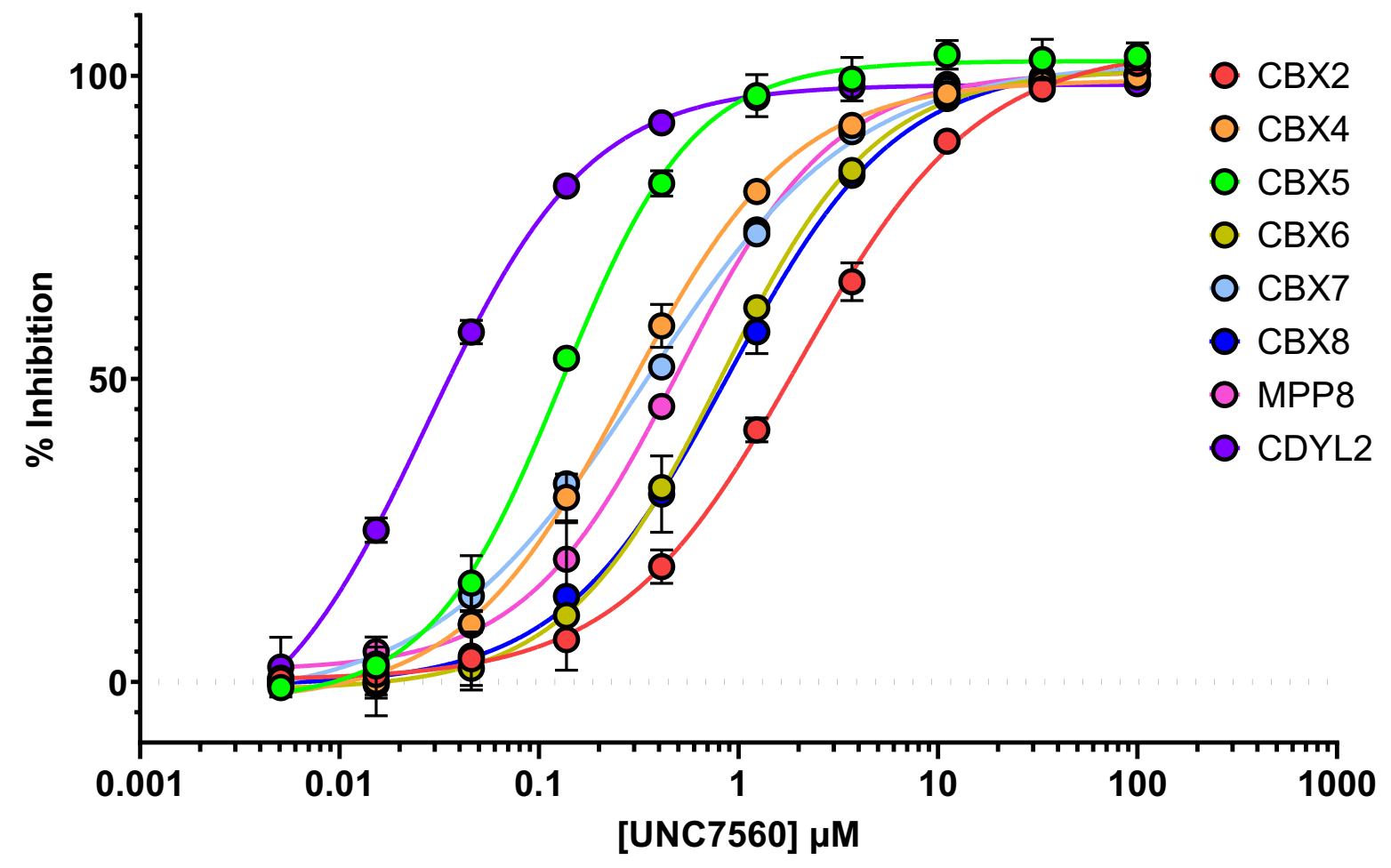

Figure S6. TR-FRET Curves of UNC7560 with Individual Chromodomains. Data is presented as mean $\pm \mathrm{SD}$ of three separate TR-FRET experiments with chromodomains and UNC7560 ligand.

\section{MPP8}
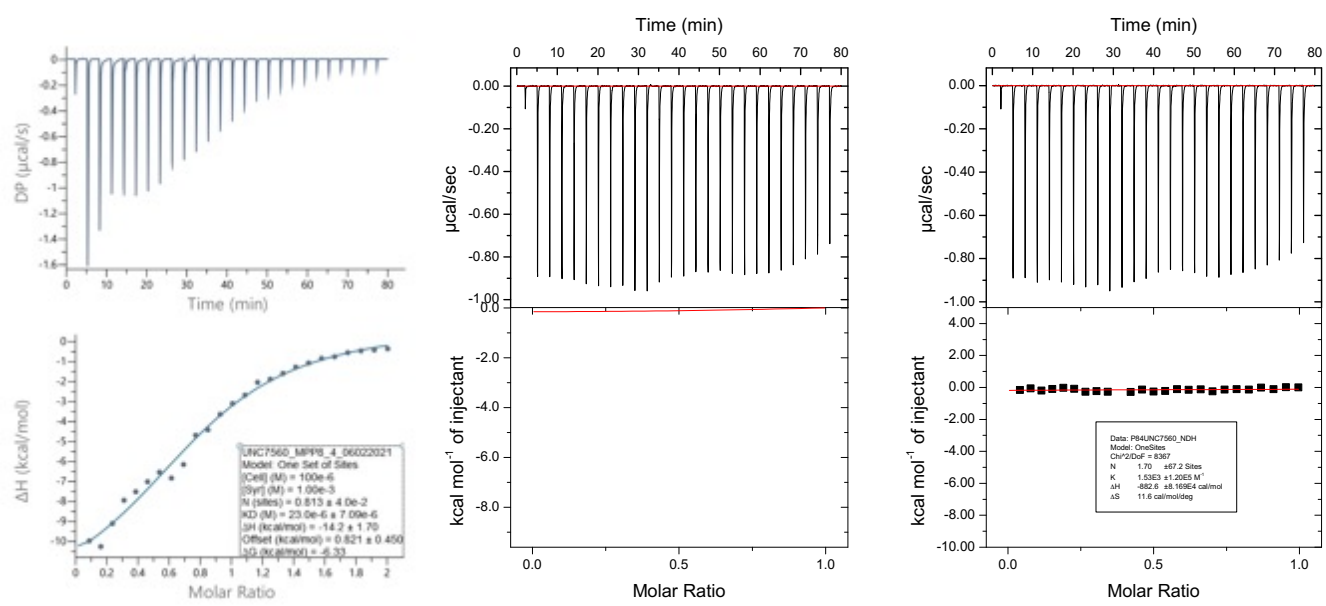

Figure S7. ITC Curves of UNC7560 with MPP8. Individual ITC curves of MPP8 protein and UNC7560 ligand, demonstrating that MPP8 weakly binds UNC7560 by ITC. 


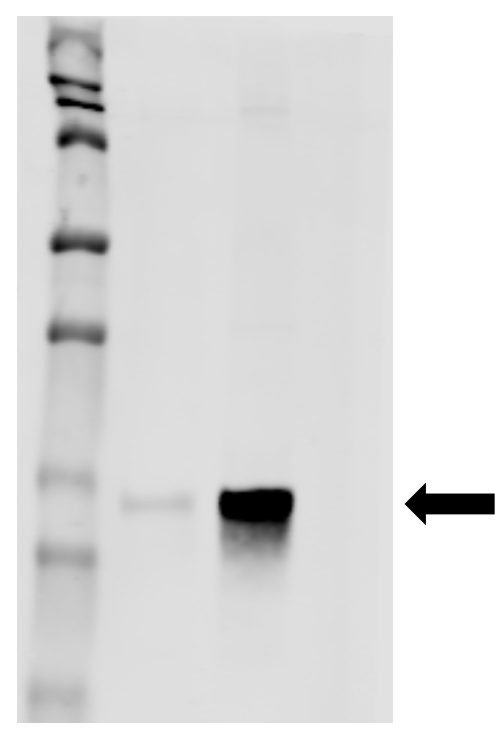

CBX1

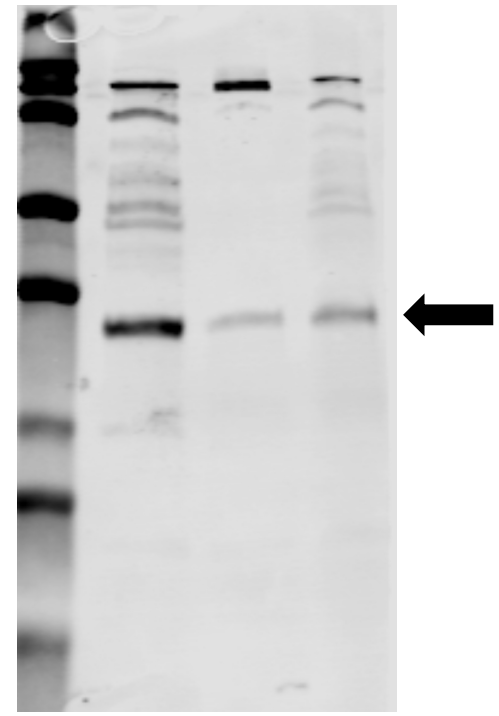

CBX7

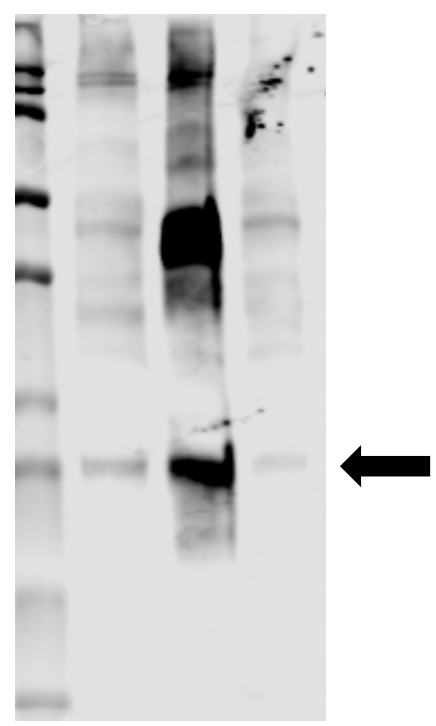

CBX3

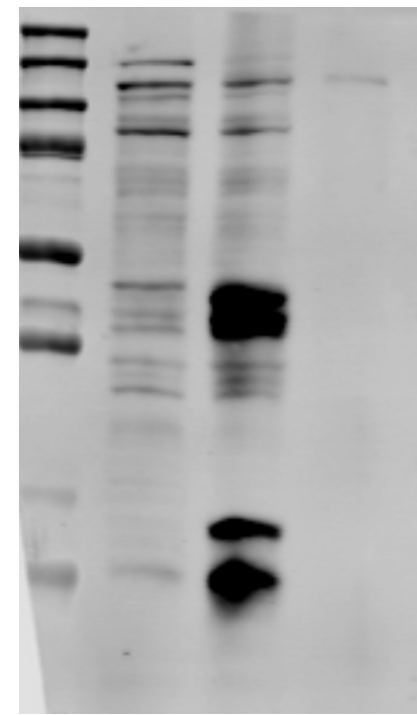

MPP8

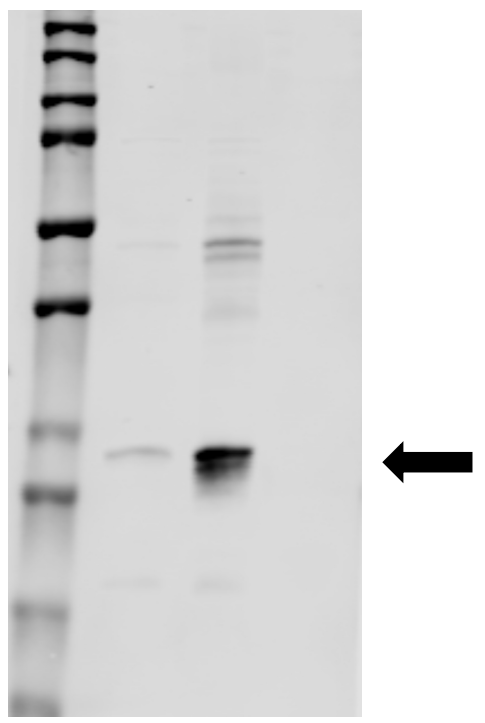

CBX5

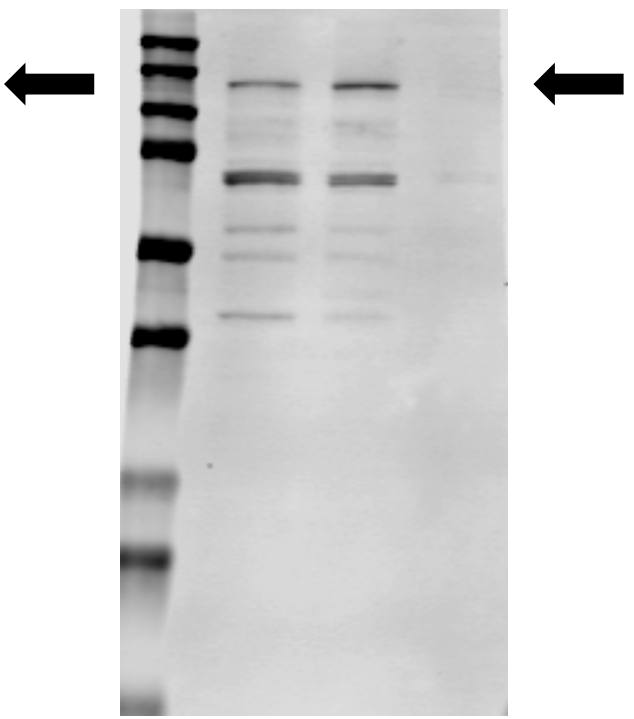

SENP7

Figure S8. Uncropped western blots for individual proteins. For all blots, Lane 1= BioRad Precision Plus Protein Dual Color Standards (\#1610374), Lane 2= HE293T Lysate Input, Lane $3=$ UNC7565 pulldown, and Lane 4= UNC7565 pulldown with UNC7560 soluble competitor competition. Western blots shown are representative of two replicate experiments. Arrow to the right of each blot denotes protein band. 


\section{Supplementary Scheme I. Synthesis of Peptide Intermediates and UNC7560}

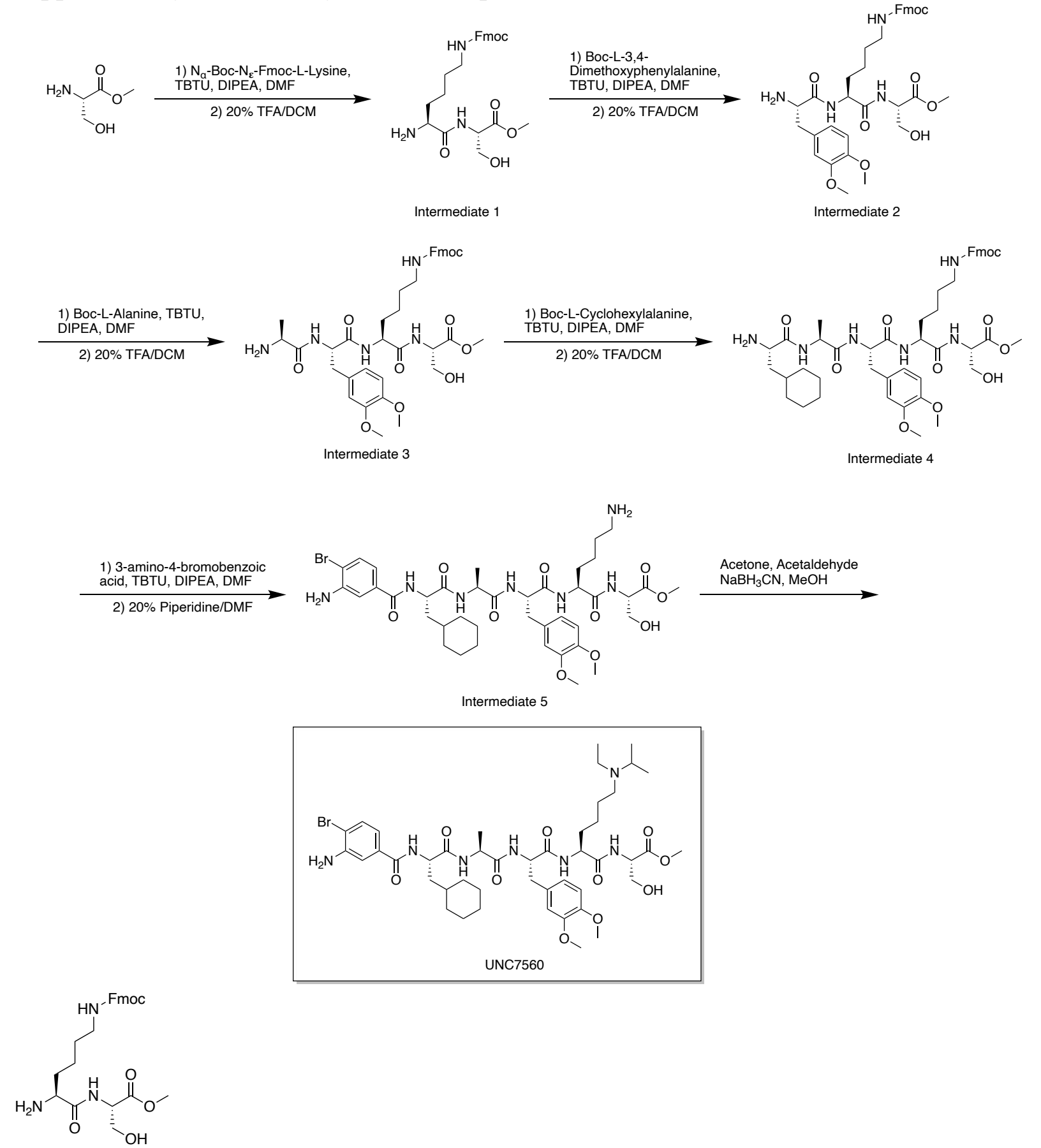

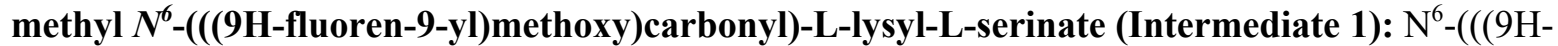
fluoren-9-yl)methoxy)carbonyl)- $\mathrm{N}^{2}$-(tert-butoxycarbonyl)-L-lysine (3.00 g, 1.00 Eq, $\left.6.40 \mathrm{mmol}\right)$, TBTU $(2.47 \mathrm{~g}, 1.20 \mathrm{Eq}, 7.68 \mathrm{mmol})$, and DIPEA $(1.70 \mathrm{~mL}, 1.50 \mathrm{Eq}, 19.2 \mathrm{mmol})$ were added to a $500 \mathrm{~mL} \mathrm{RB}$ flask in DMF $(20 \mathrm{~mL})$ and DCM $(150 \mathrm{~mL})$ and stirred for $10 \mathrm{~min}$ to allow for pre-activation of the amino acid to be coupled. (S)-3-hydroxy-1-methoxy-1-oxopropan-2-aminium chloride (1.10 g, 1.10 Eq, 7.04 mmol) and DIPEA $(1.70 \mathrm{~mL}, 1.50 \mathrm{Eq}, 19.2 \mathrm{mmol})$ were added to a separate flask in $10 \mathrm{~mL}$ DMF to allow for neutralization of the $\mathrm{HCl}$ salt. After $10 \mathrm{~min}$, contents of the second flask were added dropwise to the first flask and the reaction mixture was stirred for 16 hour at $25^{\circ} \mathrm{C}$. The reaction mixture was then concentrated under reduced pressure, re-dissolved in $50 \mathrm{~mL}$ of DCM, and combined with an equal portion 
of brine. Product was extracted with 3 x $100 \mathrm{~mL}$ DCM, dried over $\mathrm{Na}_{2} \mathrm{SO}_{4}$, and concentrated under reduced pressure. Crude product was purified by normal phase chromatography on a Flash Column ISCO using a DCM:MeOH gradient, and eluted at $\sim 10 \% \mathrm{MeOH}$. Product fractions were concentrated under reduced pressure. Concentrate was then dissolved in 20\% TFA in DCM in a $250 \mathrm{~mL}$ RB flask. The reaction mixture was stirred for 2 hour at $25^{\circ} \mathrm{C}$, and product formation was monitored by LCMS. Upon conversion of the Boc-protected intermediate to the deprotected product, the reaction mixture was concentrated under reduced pressure. Crude product was purified by reverse phase chromatography on a Flash Column ISCO using a $\left(\mathrm{H}_{2} \mathrm{O}+0.1 \%\right.$ TFA $): \mathrm{MeOH}$ gradient to yield $2.60 \mathrm{~g}(69.6 \%$ yield $)$ of the TFA salt of the title compound as a clear oil.

${ }^{1} \mathrm{H}$ NMR (400 MHz, Methanol- $\left.d_{4}\right) \delta 7.80(\mathrm{~d}, J=7.5 \mathrm{~Hz}, 2 \mathrm{H}), 7.64(\mathrm{~d}, J=7.4 \mathrm{~Hz}, 2 \mathrm{H}), 7.39(\mathrm{t}, J=7.4 \mathrm{~Hz}$, $2 \mathrm{H}), 7.31(\mathrm{t}, J=7.4 \mathrm{~Hz}, 2 \mathrm{H}), 4.58(\mathrm{t}, J=4.4 \mathrm{~Hz}, 1 \mathrm{H}), 4.36(\mathrm{~d}, J=6.8 \mathrm{~Hz}, 2 \mathrm{H}), 4.20(\mathrm{t}, J=6.8 \mathrm{~Hz}, 1 \mathrm{H})$, $3.97-3.90(\mathrm{~m}, 2 \mathrm{H}), 3.83(\mathrm{dd}, J=11.2,3.9 \mathrm{~Hz}, 1 \mathrm{H}), 3.71(\mathrm{~s}, 3 \mathrm{H}), 3.14(\mathrm{t}, J=6.6 \mathrm{~Hz}, 2 \mathrm{H}), 1.99-1.80(\mathrm{~m}$, $2 \mathrm{H}), 1.61-1.41(\mathrm{~m}, 4 \mathrm{H})$. MSI (ESI): $470[\mathrm{M}+\mathrm{H}]^{+} . t_{\mathrm{R}}=3.62 \mathrm{~min}$.

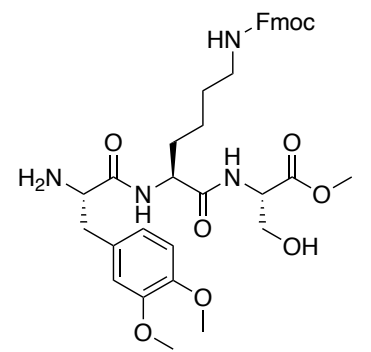

methyl $N^{6}$-(((9H-fluoren-9-yl)methoxy)carbonyl)- $N^{2}-((\mathrm{S})-2$-amino-3-(3,4dimethoxyphenyl)propanoyl)-L-lysyl-L-serinate (Intermediate 2): (S)-2-((tertbutoxycarbonyl)amino)-3-(3,4-dimethoxyphenyl)propanoic acid (731 mg, 0.950 Eq, $2.25 \mathrm{mmol})$, TBTU (911 mg, $1.20 \mathrm{Eq}, 2.84 \mathrm{mmol})$, and DIPEA $(0.600 \mathrm{~mL}, 1.50 \mathrm{Eq}, 3.55 \mathrm{mmol})$ were added to a $500 \mathrm{~mL}$ RB flask in DMF $(20 \mathrm{~mL})$ and DCM $(150 \mathrm{~mL})$ and stirred for $10 \mathrm{~min}$ to allow for pre-activation of the amino acid to be coupled. (9S,12S)-1-(9H-fluoren-9-yl)-12-(hydroxymethyl)-3,10,13-trioxo-2,14-dioxa-4,11diazapentadecan-9-aminium 2,2,2-trifluoroacetate $(1.38 \mathrm{~g}, 1.00 \mathrm{Eq}, 2.36 \mathrm{mmol})$ and DIPEA (0.600 mL, $1.50 \mathrm{Eq}, 3.55 \mathrm{mmol}$ ) were added to a separate flask in $10 \mathrm{~mL}$ DMF to allow for neutralization of the TFA salt. After $10 \mathrm{~min}$, contents of the second flask were added dropwise to the first flask and the reaction mixture was stirred for 16 hour at $25^{\circ} \mathrm{C}$. The reaction mixture was then concentrated under reduced pressure, re-dissolved in $50 \mathrm{~mL}$ of DCM, and combined with an equal portion of brine. Product was extracted with $3 \times 100 \mathrm{~mL}$ DCM, dried over $\mathrm{Na}_{2} \mathrm{SO}_{4}$, and concentrated under reduced pressure. Concentrate was then dissolved in 20\% TFA in DCM in a $250 \mathrm{~mL}$ RB flask. The reaction mixture was stirred for 2 hour at $25^{\circ} \mathrm{C}$, and product formation was monitored by LCMS. Upon conversion of the Bocprotected intermediate to the deprotected product, the reaction mixture was concentrated under reduced pressure. Crude product was purified by reverse phase chromatography on a Flash Column ISCO using a $\left(\mathrm{H}_{2} \mathrm{O}+0.1 \%\right.$ TFA $): \mathrm{MeOH}$ gradient to yield $1.53 \mathrm{~g}$ (81.8\% yield) of the TFA salt of the title compound as a clear oil.

${ }^{1} \mathrm{H}$ NMR (400 MHz, Methanol- $\left.d_{4}\right) \delta 7.80(\mathrm{~d}, J=7.5 \mathrm{~Hz}, 2 \mathrm{H}), 7.64(\mathrm{~d}, J=7.4 \mathrm{~Hz}, 2 \mathrm{H}), 7.39(\mathrm{t}, J=7.4 \mathrm{~Hz}$, $2 \mathrm{H}), 7.31(\mathrm{t}, J=7.7 \mathrm{~Hz}, 2 \mathrm{H}), 6.95-6.86(\mathrm{~m}, 2 \mathrm{H}), 6.82(\mathrm{dd}, J=8.2,1.9 \mathrm{~Hz}, 1 \mathrm{H}), 4.54-4.42(\mathrm{~m}, 2 \mathrm{H})$, $4.35(\mathrm{~d}, J=6.8 \mathrm{~Hz}, 2 \mathrm{H}), 4.20(\mathrm{t}, J=6.8 \mathrm{~Hz}, 1 \mathrm{H}), 4.14-4.07(\mathrm{~m}, 1 \mathrm{H}), 3.92(\mathrm{dd}, J=11.3,4.8 \mathrm{~Hz}, 1 \mathrm{H})$, $3.85-3.77(\mathrm{~m}, 7 \mathrm{H}), 3.72(\mathrm{~s}, 3 \mathrm{H}), 3.21(\mathrm{dd}, J=14.5,5.2 \mathrm{~Hz}, 1 \mathrm{H}), 3.12(\mathrm{t}, J=6.8 \mathrm{~Hz}, 2 \mathrm{H}), 2.96(\mathrm{dd}, J=$ $14.4,8.6 \mathrm{~Hz}, 1 \mathrm{H}), 1.94-1.23(\mathrm{~m}, 6 \mathrm{H})$. MSI (ESI): $677[\mathrm{M}+\mathrm{H}]^{+} . t_{\mathrm{R}}=3.88 \mathrm{~min}$. 


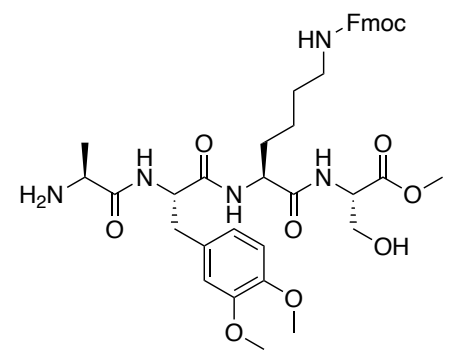

methyl $N^{6}-\left(((9 H-f l u o r e n-9-y l) m e t h o x y)\right.$ carbonyl)- $N^{2}-((\mathrm{S})-2-((\mathrm{S})-2-$ aminopropanamido)-3-(3,4dimethoxyphenyl)propanoyl)-L-lysyl-L-serinate (Intermediate 3): (tert-butoxycarbonyl)-L-alanine (348 mg, $0.950 \mathrm{Eq}, 1.84 \mathrm{mmol})$, TBTU (621 mg, 1.00 Eq, $1.93 \mathrm{mmol})$, and DIPEA (0.500 mL, $1.50 \mathrm{Eq}$, $2.90 \mathrm{mmol})$ were added to a $250 \mathrm{~mL}$ RB flask in DMF $(10 \mathrm{~mL})$ and DCM $(100 \mathrm{~mL})$ and stirred for 10 min to allow for pre-activation of the amino acid to be coupled. (S)-1-(( $9 \mathrm{~S}, 12 \mathrm{~S})-1-(9 \mathrm{H}-$ fluoren-9-yl)-12(hydroxymethyl)-3,10,13-trioxo-2,14-dioxa-4,11-diazapentadecan-9-yl)amino)-3-(3,4-dimethoxyphenyl)1-oxopropan-2-aminium 2,2,2-trifluoroacetate (1.53 g, $1.00 \mathrm{Eq}, 1.93 \mathrm{mmol})$ and DIPEA (0.500 mL, 1.50 Eq, $2.90 \mathrm{mmol}$ ) were added to a separate flask in $10 \mathrm{~mL}$ DMF to allow for neutralization of the TFA salt. After $10 \mathrm{~min}$, contents of the second flask were added dropwise to the first flask and the reaction mixture was stirred for 16 hour at $25^{\circ} \mathrm{C}$. The reaction mixture was then concentrated under reduced pressure, redissolved in $50 \mathrm{~mL}$ of DCM, and combined with an equal portion of brine. Product was extracted with $3 \mathrm{x}$ $100 \mathrm{~mL}$ DCM, dried over $\mathrm{Na}_{2} \mathrm{SO}_{4}$, and concentrated under reduced pressure. Concentrate was then dissolved in 20\% TFA in DCM in a $200 \mathrm{~mL}$ RB flask. The reaction mixture was stirred for 2 hour at $25^{\circ} \mathrm{C}$, and product formation was monitored by LCMS. Upon conversion of the Boc-protected intermediate to the deprotected product, the reaction mixture was concentrated under reduced pressure. Crude product was purified by reverse phase chromatography on a Flash Column ISCO using a $\left(\mathrm{H}_{2} \mathrm{O}+0.1 \%\right.$ TFA): $\mathrm{MeOH}$ gradient to yield $541 \mathrm{mg}$ (32.4\% yield) of the TFA salt of the title compound as a clear oil.

${ }^{1} \mathrm{H}$ NMR (400 MHz, Methanol- $\left.d_{4}\right) \delta 7.79(\mathrm{~d}, J=7.5 \mathrm{~Hz}, 2 \mathrm{H}), 7.63(\mathrm{~d}, J=7.4 \mathrm{~Hz}, 2 \mathrm{H}), 7.39$ (t, $J=7.4 \mathrm{~Hz}$, $2 \mathrm{H}), 7.30(\mathrm{t}, J=7.4 \mathrm{~Hz}, 2 \mathrm{H}), 6.92-6.78(\mathrm{~m}, 3 \mathrm{H}), 4.69-4.62(\mathrm{~m}, 1 \mathrm{H}), 4.48(\mathrm{t}, J=4.4 \mathrm{~Hz}, 1 \mathrm{H}), 4.43-$ $4.37(\mathrm{~m}, 1 \mathrm{H}), 4.34(\mathrm{~d}, J=6.8 \mathrm{~Hz}, 2 \mathrm{H}), 4.19(\mathrm{t}, J=6.8 \mathrm{~Hz}, 1 \mathrm{H}), 3.95-3.76(\mathrm{~m}, 8 \mathrm{H}), 3.72(\mathrm{~s}, 3 \mathrm{H}), 3.17-$ $2.77(\mathrm{~m}, 4 \mathrm{H}), 1.91-1.23(\mathrm{~m}, 9 \mathrm{H})$. MSI (ESI): $748[\mathrm{M}+\mathrm{H}]^{+} . t_{\mathrm{R}}=3.57 \mathrm{~min}$.

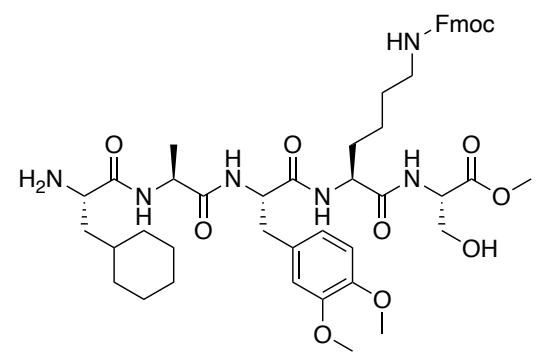

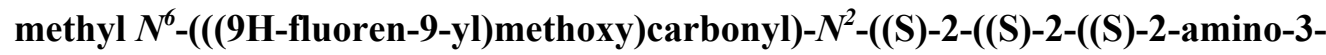
cyclohexylpropanamido)propanamido)-3-(3,4-dimethoxyphenyl)propanoyl)-L-lysyl-L-serinate (Intermediate 4): (S)-2-((tert-butoxycarbonyl)amino)-3-cyclohexylpropanoic acid (80.8 mg, $0.95 \mathrm{Eq}$, $298 \mu \mathrm{mol})$, TBTU $(101 \mathrm{mg}, 1.00 \mathrm{Eq}, 313 \mu \mathrm{mol})$, and DIPEA $(0.800 \mathrm{~mL}, 1.50 \mathrm{Eq}, 460 \mu \mathrm{mol})$ were added to a $200 \mathrm{~mL}$ RB flask in DMF $(10 \mathrm{~mL})$ and DCM $(100 \mathrm{~mL})$ and stirred for $10 \mathrm{~min}$ to allow for preactivation of the amino acid to be coupled. (9S,12S,15S)-12-(3,4-dimethoxybenzyl)-1-(9H-fluoren-9-yl)9-(((S)-3-hydroxy-1-methoxy-1-oxopropan-2-yl)carbamoyl)-3,11,14-trioxo-2-oxa-4,10,13triazahexadecan-15-aminium 2,2,2-trifluoroacetate $(270 \mathrm{mg}, 1.00 \mathrm{Eq}, 313 \mu \mathrm{mol})$ and DIPEA $(0.800 \mathrm{~mL}$, $1.50 \mathrm{Eq}, 460 \mu \mathrm{mol}$ ) were added to a separate flask in $10 \mathrm{~mL}$ DMF to allow for neutralization of the TFA salt. After $10 \mathrm{~min}$, contents of the second flask were added dropwise to the first flask and the reaction mixture was stirred for 16 hour at $25^{\circ} \mathrm{C}$. The reaction mixture was then concentrated under reduced 
pressure, re-dissolved in $50 \mathrm{~mL}$ of DCM, and combined with an equal portion of brine. Product was extracted with 3 x $50 \mathrm{~mL}$ DCM, dried over $\mathrm{Na}_{2} \mathrm{SO}_{4}$, and concentrated under reduced pressure.

Concentrate was then dissolved in 20\% TFA in DCM in a $100 \mathrm{~mL}$ RB flask. The reaction mixture was stirred for 2 hour at $25^{\circ} \mathrm{C}$, and product formation was monitored by LCMS. Upon conversion of the Bocprotected intermediate to the deprotected product, the reaction mixture was concentrated under reduced pressure. Crude product was purified by reverse phase chromatography on a Flash Column ISCO using a $\left(\mathrm{H}_{2} \mathrm{O}+0.1 \%\right.$ TFA):MeOH gradient to yield $268 \mathrm{mg}$ ( $84.3 \%$ yield) of the TFA salt of the title compound as a clear oil.

${ }^{1} \mathrm{H}$ NMR (400 MHz, Methanol- $\left.d_{4}\right) \delta 7.79(\mathrm{~d}, J=7.5 \mathrm{~Hz}, 2 \mathrm{H}), 7.63(\mathrm{t}, J=6.8 \mathrm{~Hz}, 2 \mathrm{H}), 7.39(\mathrm{t}, J=7.5 \mathrm{~Hz}$, $2 \mathrm{H}), 7.35-7.26(\mathrm{~m}, 2 \mathrm{H}), 6.90-6.75(\mathrm{~m}, 3 \mathrm{H}), 4.60-4.54(\mathrm{~m}, 1 \mathrm{H}), 4.52-4.45(\mathrm{~m}, 1 \mathrm{H}), 4.44-4.37(\mathrm{~m}$, $2 \mathrm{H}), 4.33(\mathrm{~d}, J=6.6 \mathrm{~Hz}, 1 \mathrm{H}), 4.18(\mathrm{t}, J=7.1 \mathrm{~Hz}, 1 \mathrm{H}), 3.94-3.76(\mathrm{~m}, 8 \mathrm{H}), 3.72(\mathrm{~s}, 3 \mathrm{H}), 3.16-2.85(\mathrm{~m}$, $4 \mathrm{H}), 1.91-1.08(\mathrm{~m}, 20 \mathrm{H}), 1.00-0.83(\mathrm{~m}, 2 \mathrm{H})$. MSI (ESI): $901[\mathrm{M}+\mathrm{H}]^{+}, 451[\mathrm{M}+2 \mathrm{H}]^{2+} \cdot t_{\mathrm{R}}=4.12 \mathrm{~min}$.

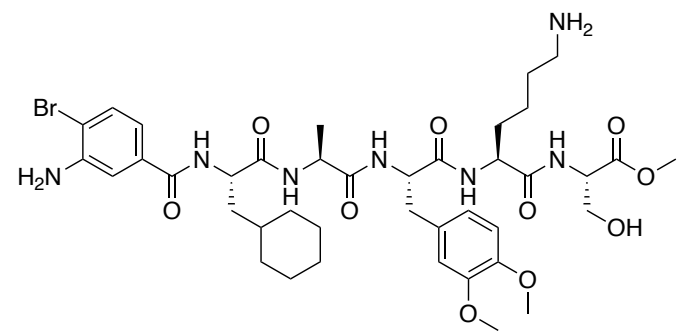

methyl ((S)-2-((S)-2-((S)-2-(3-amino-4-bromobenzamido)-3-cyclohexylpropanamido)propanamido)3-(3,4-dimethoxyphenyl)propanoyl)-L-lysyl-L-serinate (Intermediate 5): 3-amino-4-bromobenzoic acid $(27.1 \mathrm{mg}, 0.950 \mathrm{Eq}, 125 \mu \mathrm{mol})$, TBTU (42.4 mg, $1.00 \mathrm{Eq}, 132 \mu \mathrm{mol})$, and DIPEA $(34.5 \mu \mathrm{L}, 1.50 \mathrm{Eq}$, $198 \mu \mathrm{mol})$ were added to a $100 \mathrm{~mL} \mathrm{RB}$ flask in DMF $(2 \mathrm{~mL})$ and DCM $(30 \mathrm{~mL})$ and stirred for $10 \mathrm{~min}$ to allow for pre-activation of the amino acid to be coupled. (9S,12S, 15S, 18S)-19-cyclohexyl-12-(3,4dimethoxybenzyl)-1-(9H-fluoren-9-yl)-9-(((S)-3-hydroxy-1-methoxy-1-oxopropan-2-yl)carbamoyl)-15methyl-3,11,14,17-tetraoxo-2-oxa-4,10,13,16-tetraazanonadecan-18-aminium 2,2,2-trifluoroacetate (134 $\mathrm{mg}, 1.00 \mathrm{Eq}, 132 \mu \mathrm{mol})$ and DIPEA $(34.5 \mu \mathrm{L}, 1.50 \mathrm{Eq}, 198 \mu \mathrm{mol})$ were added to a separate flask in 10 $\mathrm{mL}$ DMF to allow for neutralization of the TFA salt. After $10 \mathrm{~min}$, contents of the second flask were added dropwise to the first flask and the reaction mixture was stirred for 16 hour at $25^{\circ} \mathrm{C}$. The reaction mixture was then concentrated under reduced pressure, re-dissolved in $50 \mathrm{~mL}$ of DCM, and combined with an equal portion of brine. Product was extracted with $3 \times 100 \mathrm{~mL} \mathrm{DCM}$, dried over $\mathrm{Na}_{2} \mathrm{SO}_{4}$, and concentrated under reduced pressure. Concentrate was then dissolved in $20 \%$ piperidine in DMF in a 100 $\mathrm{mL}$ RB flask. The reaction mixture was stirred for 16 hour at $25^{\circ} \mathrm{C}$, and product formation was monitored by LCMS. Upon conversion of the Fmoc-protected intermediate to the deprotected product, the reaction mixture was concentrated under reduced pressure. Crude product was purified by reverse phase chromatography on a Flash Column ISCO using a $\left(\mathrm{H}_{2} \mathrm{O}+0.1 \%\right.$ TFA): $\mathrm{MeOH}$ gradient to yield $109 \mathrm{mg}$ ( $83.4 \%$ yield) of the TFA salt of the title compound as a clear oil.

${ }^{1} \mathrm{H}$ NMR (400 MHz, Methanol- $\left.d_{4}\right) \delta 7.45(\mathrm{dd}, J=19.1,8.2 \mathrm{~Hz}, 1 \mathrm{H}), 7.32(\mathrm{~d}, J=2.1 \mathrm{~Hz}, 1 \mathrm{H}), 7.05(\mathrm{dd}, J$ $=8.3,2.1 \mathrm{~Hz}, 1 \mathrm{H}), 6.82-6.70(\mathrm{~m}, 3 \mathrm{H}), 4.59-4.40(\mathrm{~m}, 4 \mathrm{H}), 4.25(\mathrm{q}, J=7.1 \mathrm{~Hz}, 1 \mathrm{H}), 3.92(\mathrm{dd}, J=11.4$, $4.7 \mathrm{~Hz}, 1 \mathrm{H}), 3.81(\mathrm{dd}, J=11.4,3.9 \mathrm{~Hz}, 1 \mathrm{H}), 3.77(\mathrm{~s}, 3 \mathrm{H}), 3.74(\mathrm{~s}, 6 \mathrm{H}), 3.14(\mathrm{dd}, J=14.1,5.2 \mathrm{~Hz}, 1 \mathrm{H})$, $3.02-2.88(\mathrm{~m}, 3 \mathrm{H}), 1.96-1.12(\mathrm{~m}, 20 \mathrm{H}), 1.06-0.88(\mathrm{~m}, 2 \mathrm{H})$. MSI (ESI): $876[\mathrm{M}+\mathrm{H}]^{+}, 439[\mathrm{M}+2 \mathrm{H}]^{2+}$. $t_{\mathrm{R}}=3.81 \mathrm{~min}$. 


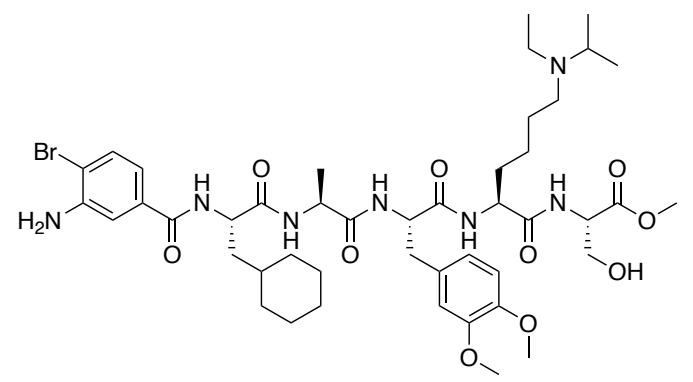

methyl $N^{2}$-((S)-2-((S)-2-((S)-2-(3-amino-4-bromobenzamido)-3cyclohexylpropanamido)propanamido)-3-(3,4-dimethoxyphenyl)propanoyl)- $N^{6}$-ethyl- $N^{6}$-isopropylL-lysyl-L-serinate (UNC7560): (3S,6S,9S,12S)-1-(3-amino-4-bromophenyl)-3-(cyclohexylmethyl)-9(3,4-dimethoxybenzyl)-12-(((S)-3-hydroxy-1-methoxy-1-oxopropan-2-yl)carbamoyl)-6-methyl-1,4,7,10tetraoxo-2,5,8,11-tetraazahexadecan-16-aminium 2,2,2-trifluoroacetate (109 mg, $1.00 \mathrm{Eq}, 110 \mu \mathrm{mol})$ was dissolved in $\mathrm{MeOH}(20 \mathrm{~mL})$ in a $50 \mathrm{~mL} \mathrm{RB}$ flask. Acetone $(120 \mu \mathrm{L}, 15.0 \mathrm{Eq}, 1.60 \mathrm{mmol})$ and sodium cyanoborohydride $(69.1 \mathrm{mg}, 10.0 \mathrm{Eq}, 1.10 \mathrm{mmol})$ were then added, and the reaction was stirred for 16 hour at $25^{\circ} \mathrm{C}$. Following conversion to the mono-substituted lysine intermediate, acetaldehyde $(93.0 \mu \mathrm{L}$, 15.0 Eq, $1.65 \mathrm{mmol}$ ) was added and the reaction was stirred for another 2 hour at $25^{\circ} \mathrm{C}$, or until complete conversion to the di-substituted lysine product. Following this, the reaction mixture was concentrated under reduced pressure. Crude product was purified by reverse phase chromatography on a Flash Column ISCO using a $\left(\mathrm{H}_{2} \mathrm{O}+0.1 \%\right.$ TFA): $\mathrm{MeOH}$ gradient to yield $53.1 \mathrm{mg}(45.5 \%$ yield $)$ of the TFA salt of the title compound as a clear oil.

${ }^{1} \mathrm{H}$ NMR $\left(400 \mathrm{MHz}\right.$, Methanol- $\left.d_{4}\right) \delta 7.48(\mathrm{~d}, J=8.3 \mathrm{~Hz}, 1 \mathrm{H}), 7.31(\mathrm{~d}, J=2.0 \mathrm{~Hz}, 1 \mathrm{H}), 7.05(\mathrm{dd}, J=8.2$, $1.9 \mathrm{~Hz}, 1 \mathrm{H}), 6.82-6.71(\mathrm{~m}, 3 \mathrm{H}), 4.58-4.41(\mathrm{~m}, 4 \mathrm{H}), 4.23(\mathrm{q}, J=7.2 \mathrm{~Hz}, 1 \mathrm{H}), 3.93(\mathrm{dd}, J=11.4,4.7$ $\mathrm{Hz}, 1 \mathrm{H}), 3.81(\mathrm{dd}, J=11.4,3.9 \mathrm{~Hz}, 1 \mathrm{H}), 3.77(\mathrm{~s}, 3 \mathrm{H}), 3.74(\mathrm{~d}, J=2.4 \mathrm{~Hz}, 6 \mathrm{H}), 3.70-3.65(\mathrm{~m}, 1 \mathrm{H}), 3.28$ $-2.92(\mathrm{~m}, 6 \mathrm{H}), 2.00-1.12(\mathrm{~m}, 29 \mathrm{H}), 1.07-0.89(\mathrm{~m}, 2 \mathrm{H})$. MSI (ESI): $946[\mathrm{M}+\mathrm{H}]^{+}, 473[\mathrm{M}+2 \mathrm{H}]^{2+} . t_{\mathrm{R}}=$ $4.27 \mathrm{~min}$. 


\section{Supplementary Scheme II. Synthesis of Carboxylic Acid Derivative, UNC7564, and Biotinylated Derivative, UNC7565}
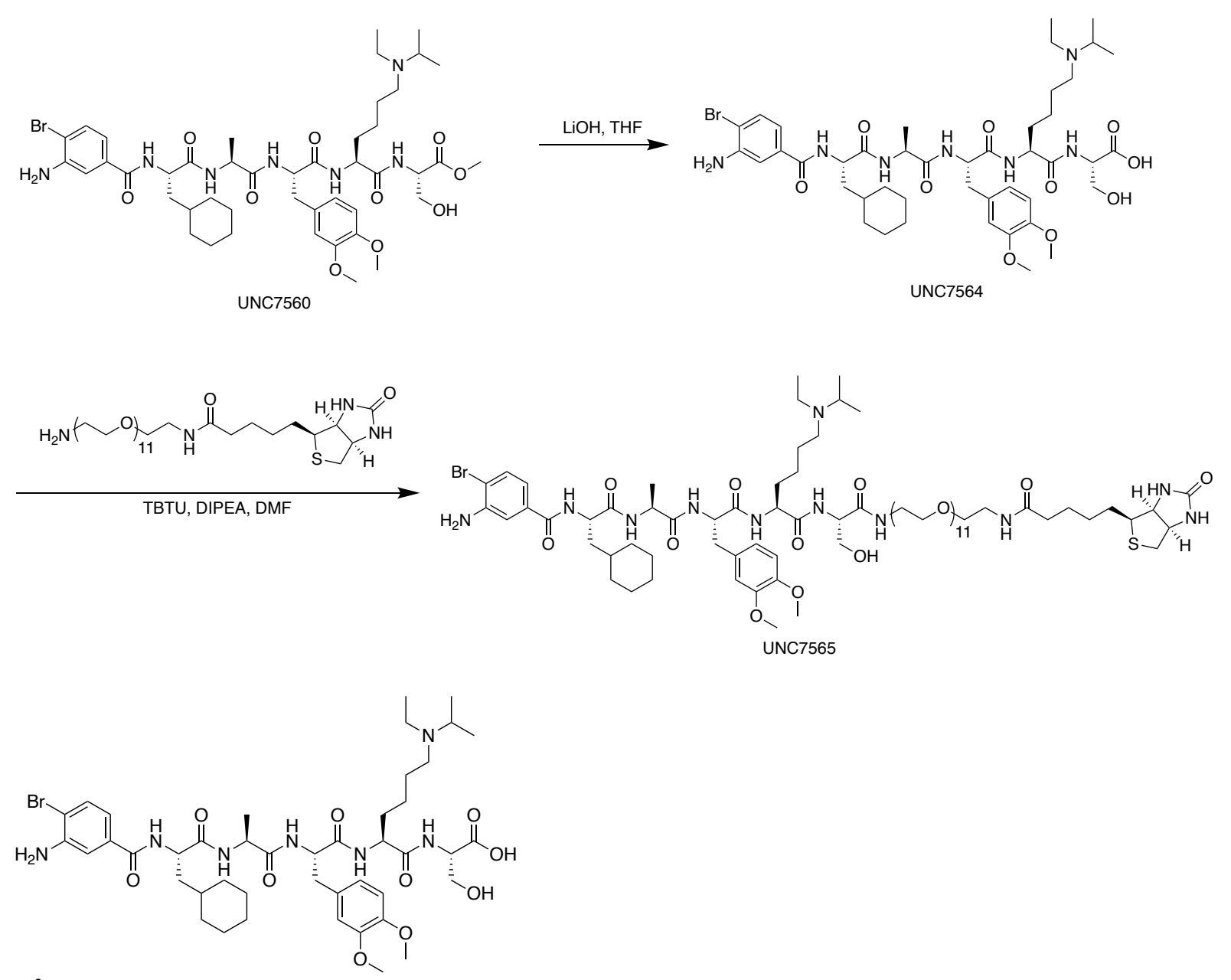

$N^{2}$-((S)-2-((S)-2-((S)-2-(3-amino-4-bromobenzamido)-3-cyclohexylpropanamido)propanamido)-3(3,4-dimethoxyphenyl)propanoyl)- $N^{6}$-ethyl- $N^{6}$-isopropyl-L-lysyl-L-serine (UNC7564):

(3S,6S,9S, 12S)-1-(3-amino-4-bromophenyl)-3-(cyclohexylmethyl)-9-(3,4-dimethoxybenzyl)-N-ethyl-12(((S)-3-hydroxy-1-methoxy-1-oxopropan-2-yl)carbamoyl)-N-isopropyl-6-methyl-1,4,7,10-tetraoxo2,5,8,11-tetraazahexadecan-16-aminium 2,2,2-trifluoroacetate $(10.0 \mathrm{mg}, 1.00 \mathrm{Eq}, 9.40 \mu \mathrm{mol})$ was dissolved in THF ( $5 \mathrm{~mL}$ ) in a $25 \mathrm{~mL}$ RB flask. $20 \mathrm{mg}$ of LiOH was then weighed out and dissolved in 400 $\mu \mathrm{L} \mathrm{H} 2 \mathrm{O}$. This solution was added to the $25 \mathrm{~mL}$ round bottom flask, and the reaction was stirred for 1 hour at $4^{\circ} \mathrm{C}$. Upon complete hydrolysis of the methyl ester to the carboxylate, reaction mixture was warmed to room temperature and $1 \mathrm{M} \mathrm{HCl}$ was added to acidify reaction mixture to a $\mathrm{pH}<2$. Acidified reaction mixture was then concentrated under reduced pressure. Crude reaction mixture was then re-dissolved in a 50:50 solution of $\mathrm{H}_{2} \mathrm{O}: \mathrm{CH}_{3} \mathrm{CN}$, and purification was completed by reverse phase chromatography on a preparative HPLC using a $(\mathrm{H} 2 \mathrm{O}+0.1 \%$ TFA): $\mathrm{CH} 3 \mathrm{CN}$ gradient to yield $7.1 \mathrm{mg}(72 \%$ yield) of the TFA salt of the title compound as a clear oil.

${ }^{1} \mathrm{H}$ NMR (400 MHz, Methanol- $\left.d_{4}\right) \delta 7.48(\mathrm{~d}, J=8.3 \mathrm{~Hz}, 1 \mathrm{H}), 7.31(\mathrm{~d}, J=2.1 \mathrm{~Hz}, 1 \mathrm{H}), 7.04(\mathrm{dd}, J=8.3$, $2.1 \mathrm{~Hz}, 1 \mathrm{H}), 6.83-6.72(\mathrm{~m}, 3 \mathrm{H}), 4.57-4.41(\mathrm{~m}, 4 \mathrm{H}), 4.23(\mathrm{q}, J=7.1 \mathrm{~Hz}, 1 \mathrm{H}), 3.94(\mathrm{dd}, J=11.3,4.8$ $\mathrm{Hz}, 1 \mathrm{H}), 3.84(\mathrm{dd}, J=11.3,3.7 \mathrm{~Hz}, 1 \mathrm{H}), 3.76(\mathrm{~d}, J=12.3 \mathrm{~Hz}, 6 \mathrm{H}), 3.72-3.63(\mathrm{~m}, 1 \mathrm{H}), 3.28-2.93(\mathrm{~m}$, $6 \mathrm{H}), 2.01-1.13(\mathrm{~m}, 29 \mathrm{H}), 1.07-0.87(\mathrm{~m}, 2 \mathrm{H})$. MSI (ESI): $932[\mathrm{M}+\mathrm{H}]^{+}, 466[\mathrm{M}+2 \mathrm{H}]^{2+} . t_{\mathrm{R}}=3.94 \mathrm{~min}$. 


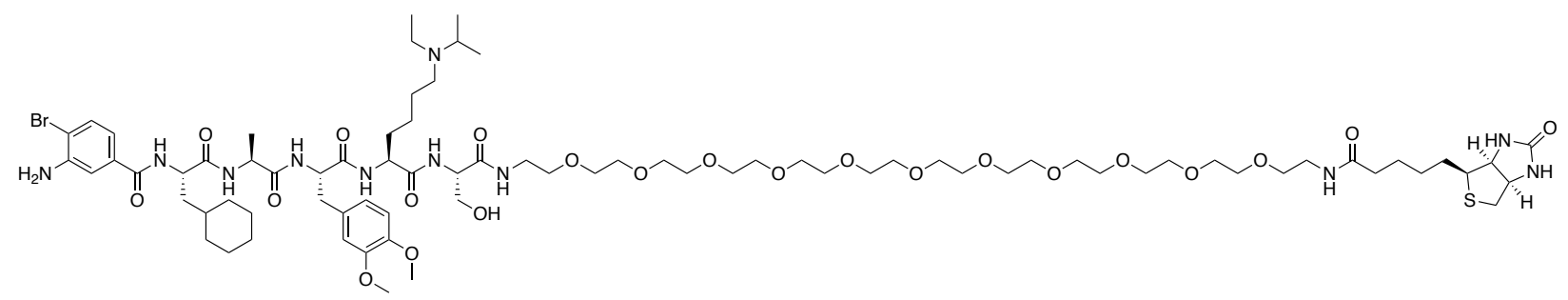

3-amino-4-bromo- $N$-((2S,5S,8S,11S,14S)-1-cyclohexyl-8-(3,4-dimethoxybenzyl)-11-(4(ethyl(isopropyl)amino)butyl)-14-(hydroxymethyl)-5-methyl-3,6,9,12,15,53-hexaoxo-57( (3aS,4S,6aR)-2-oxohexahydro- $1 H$-thieno[3,4- $d]$ imidazol-4-yl)-19,22,25,28,31,34,37,40,43,46,49undecaoxa-4,7,10,13,16,52-hexaazaheptapentacontan-2-yl)benzamide (UNC7565): (3S,6S,9S,12S)-1(3-amino-4-bromophenyl)-12-(((S)-1-carboxy-2-hydroxyethyl)carbamoyl)-3-(cyclohexylmethyl)-9-(3,4dimethoxybenzyl)-N-ethyl-N-isopropyl-6-methyl-1,4,7,10-tetraoxo-2,5,8,11-tetraazahexadecan-16aminium 2,2,2-trifluoroacetate (4.0 mg, 1.0 Eq, $3.8 \mu \mathrm{mol})$, TBTU (1.6 mg, $1.3 \mathrm{Eq}, 5.0 \mu \mathrm{mol})$, and DIPEA $(1.5 \mu \mathrm{L}, 2.2 \mathrm{Eq}, 8.4 \mu \mathrm{mol})$ were dissolved in DMF $(5 \mathrm{~mL})$ in a $25 \mathrm{~mL}$ RB flask. Separately, N(35-amino-3,6,9,12,15,18,21,24,27,30,33-undecaoxapentatriacontyl)-5-((3aS,4S,6aR)-2-oxohexahydro1H-thieno[3,4-d]imidazol-4-yl)pentanamide $(3.2 \mathrm{mg}, 1.1 \mathrm{Eq}, 4.2 \mu \mathrm{mol})$ and DIPEA $(1.5 \mu \mathrm{L}, 2.2 \mathrm{Eq}, 8.4$ $\mu \mathrm{mol})$ were dissolved in $500 \mu \mathrm{L}$ of DMF to neutralize the TFA salt of the amine. The carboxylic acid of UNC7564 was allowed to pre-activate for $5 \mathrm{~min}$, after which the contents of the second flask were added to the reaction mixture and stirred for 2 hour at $25^{\circ} \mathrm{C}$. The reaction mixture was concentrated under reduced pressure, re-dissolved in a 50:50 solution of $\mathrm{H}_{2} \mathrm{O}: \mathrm{CH}_{3} \mathrm{CN}$, and purification was completed by reverse phase chromatography on a preparative HPLC using a $\left(\mathrm{H} 2 \mathrm{O}+0.1 \%\right.$ TFA): $\mathrm{CH}_{3} \mathrm{CN}$ gradient to yield $6.0 \mathrm{mg}$ ( $87 \%$ yield) of the TFA salt of the title compound as a clear oil.

${ }^{1} \mathrm{H}$ NMR $\left(400 \mathrm{MHz}\right.$, Methanol- $\left.d_{4}\right) \delta 7.49(\mathrm{~d}, J=8.3 \mathrm{~Hz}, 1 \mathrm{H}), 7.33(\mathrm{~s}, 1 \mathrm{H}), 7.06(\mathrm{dd}, J=8.2,2.0 \mathrm{~Hz}, 1 \mathrm{H})$, $6.84-6.71(\mathrm{~m}, 3 \mathrm{H}), 4.55-4.18(\mathrm{~m}, 7 \mathrm{H}), 3.86-3.71(\mathrm{~m}, 8 \mathrm{H}), 3.71-3.51(\mathrm{~m}, 42 \mathrm{H}), 3.43-3.33(\mathrm{~m}, 4 \mathrm{H})$, $3.27-2.89(\mathrm{~m}, 8 \mathrm{H}), 2.71(\mathrm{~d}, 1 \mathrm{H}), 2.22(\mathrm{t}, J=7.4 \mathrm{~Hz}, 2 \mathrm{H}), 2.00-1.13(\mathrm{~m}, 35 \mathrm{H}), 1.08-0.89(\mathrm{~m}, 2 \mathrm{H})$. MSI (ESI): $1684[\mathrm{M}+\mathrm{H}]^{+}, 843[\mathrm{M}+2 \mathrm{H}]^{2+} . t_{\mathrm{R}}=3.82 \mathrm{~min}$. 
Figure S9. LCMS Chromatograms of Selected Compounds
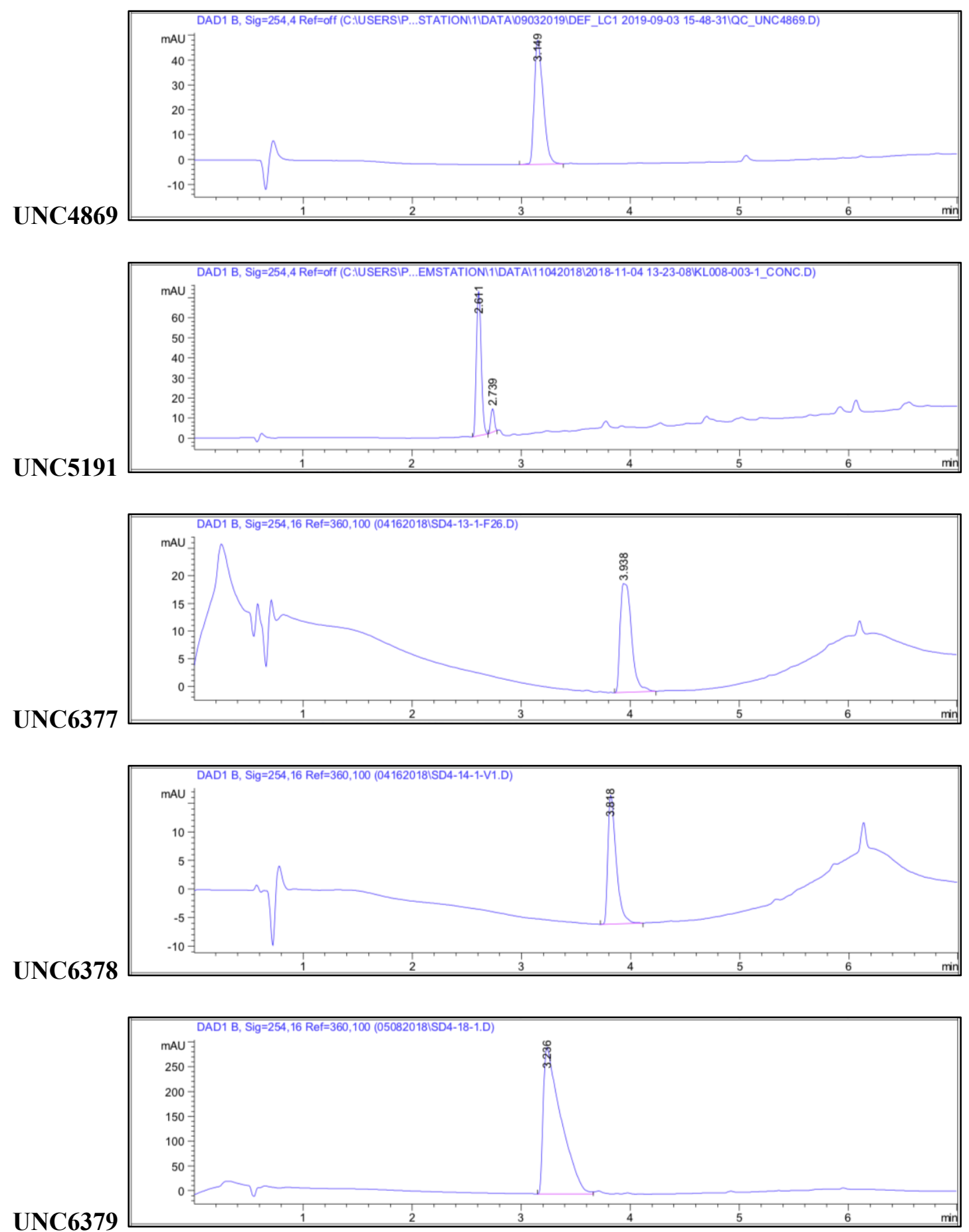

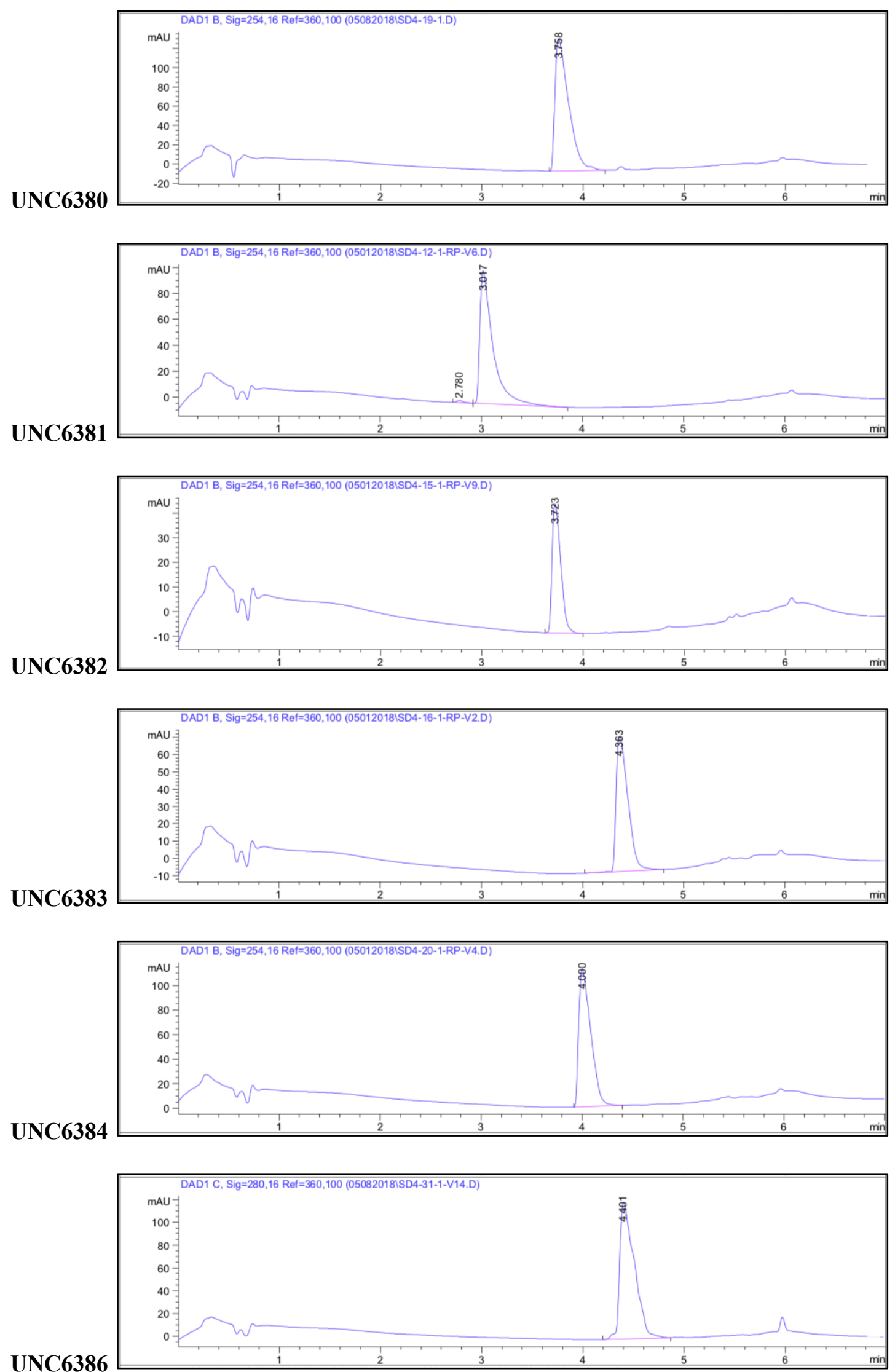

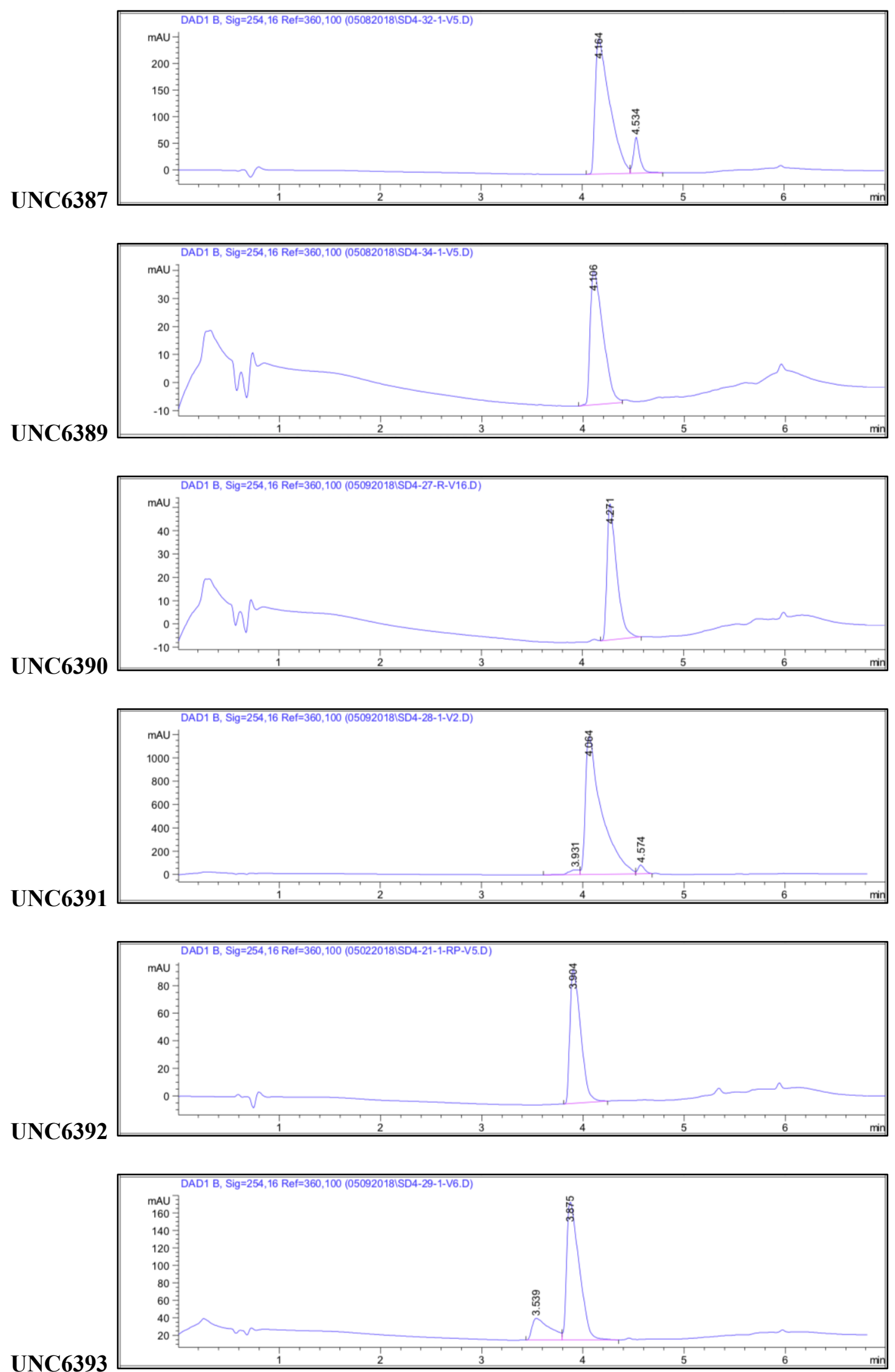

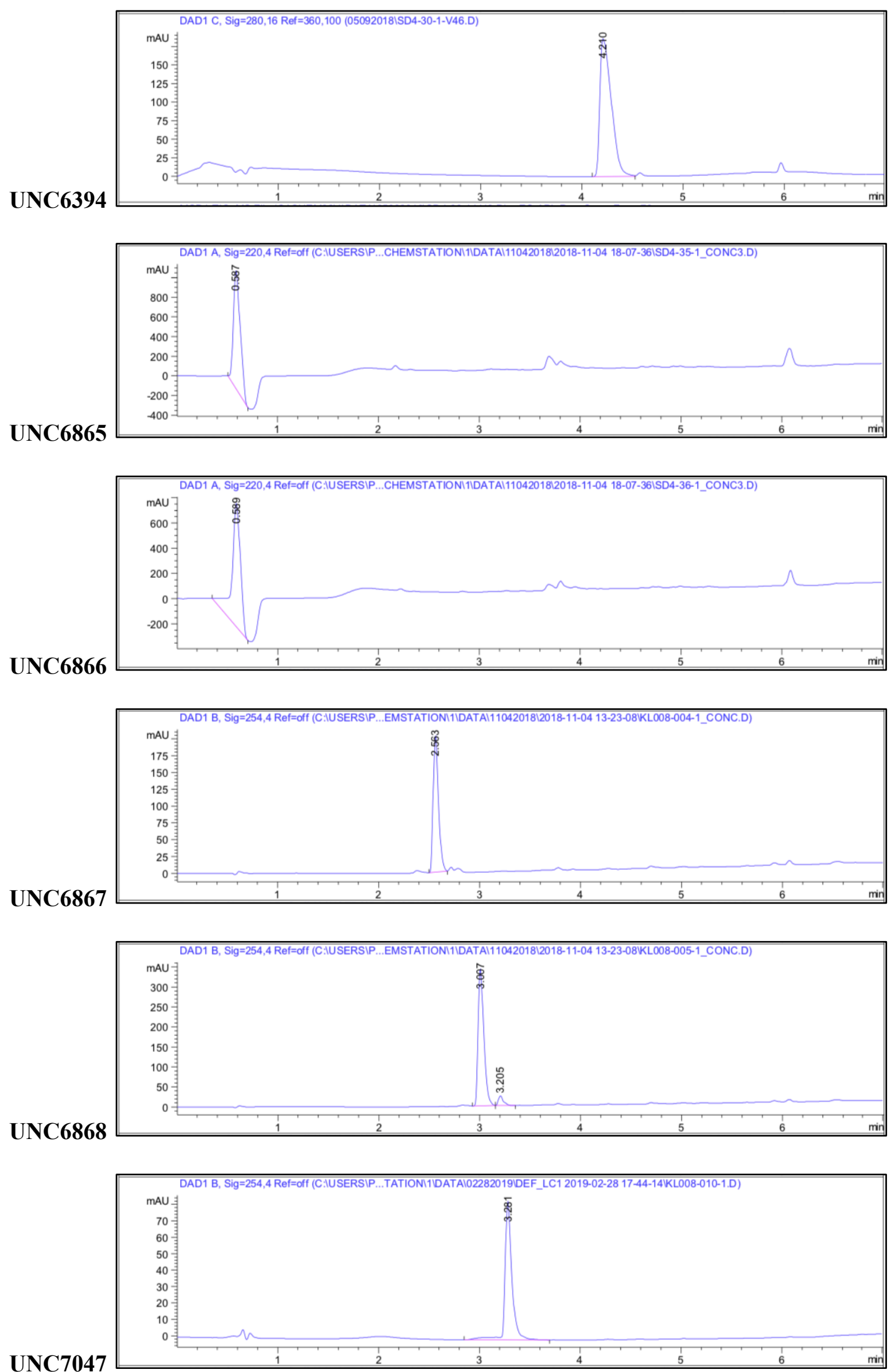

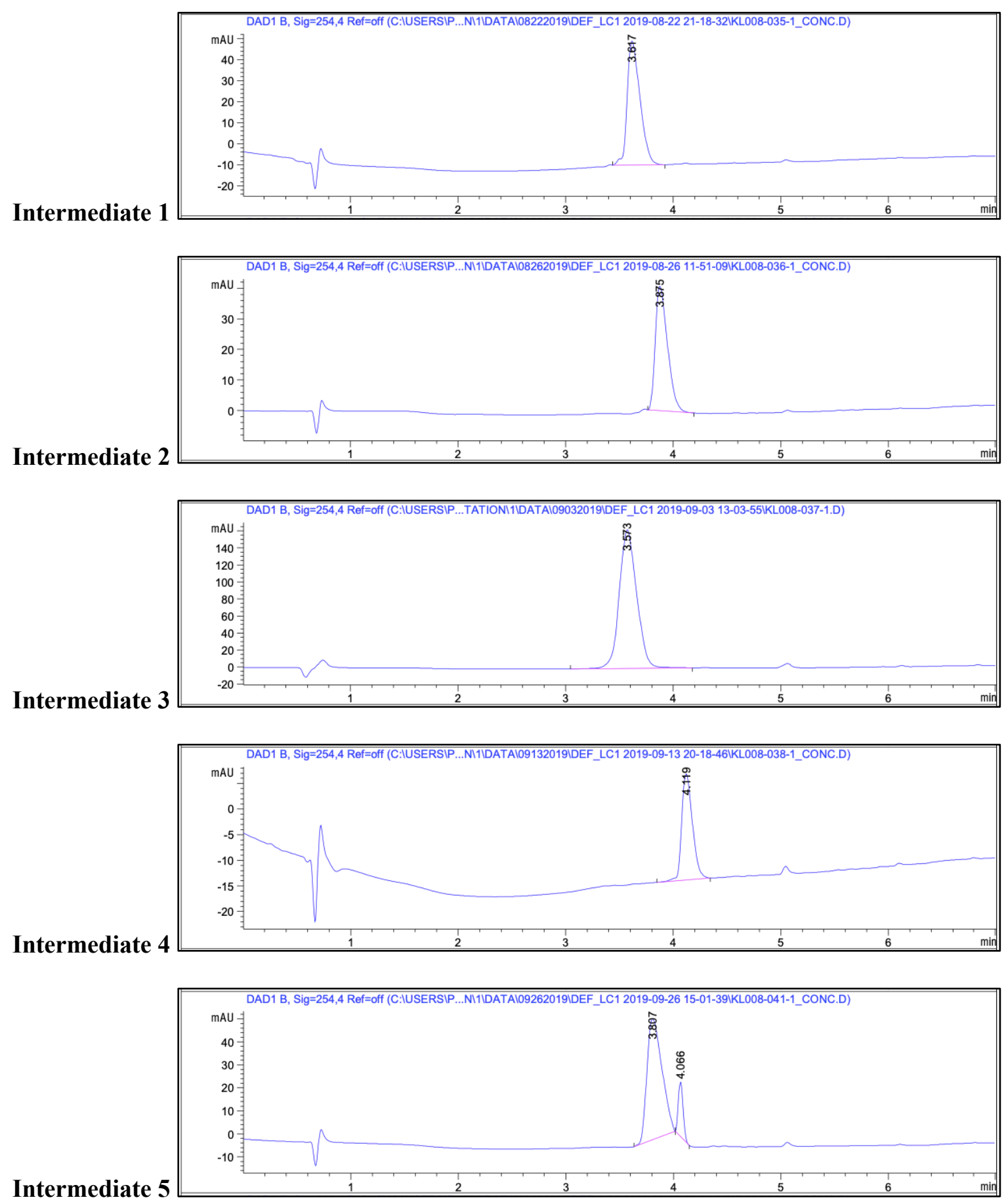

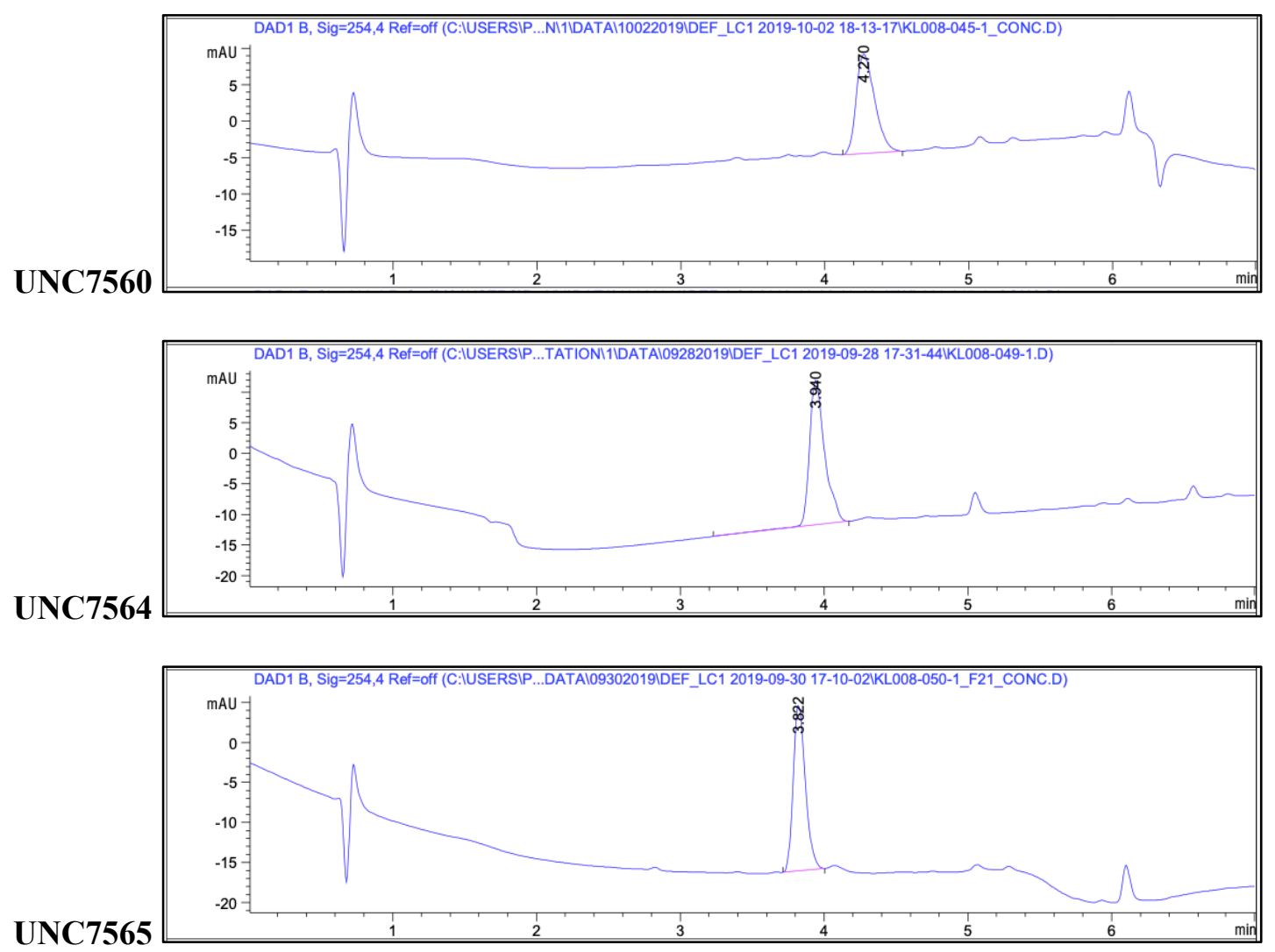
Figure S10. ${ }^{1} \mathrm{H}$ NMR Spectra of Selected Compounds as TFA Salts

\section{UNC4869}

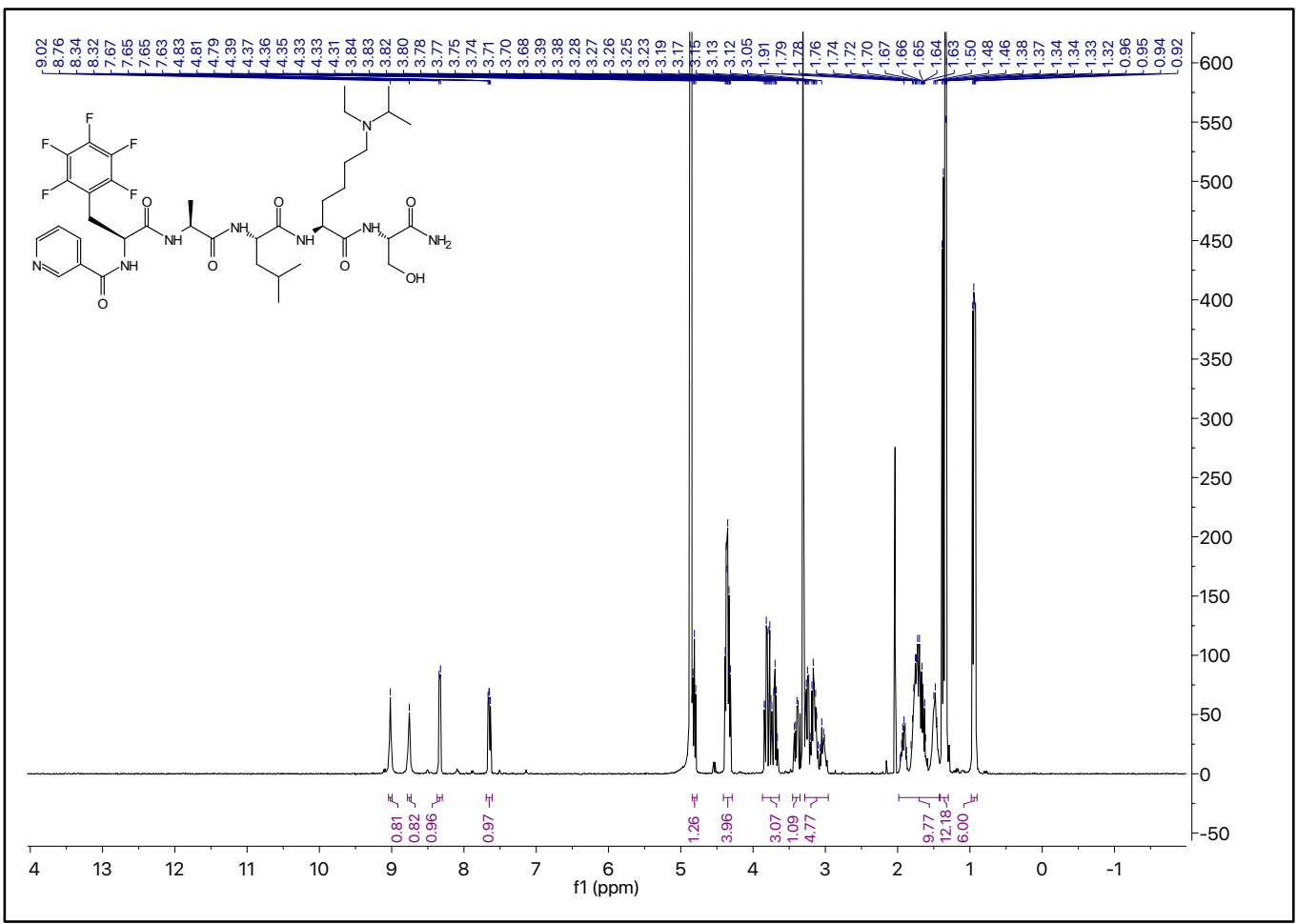

\section{UNC5191}




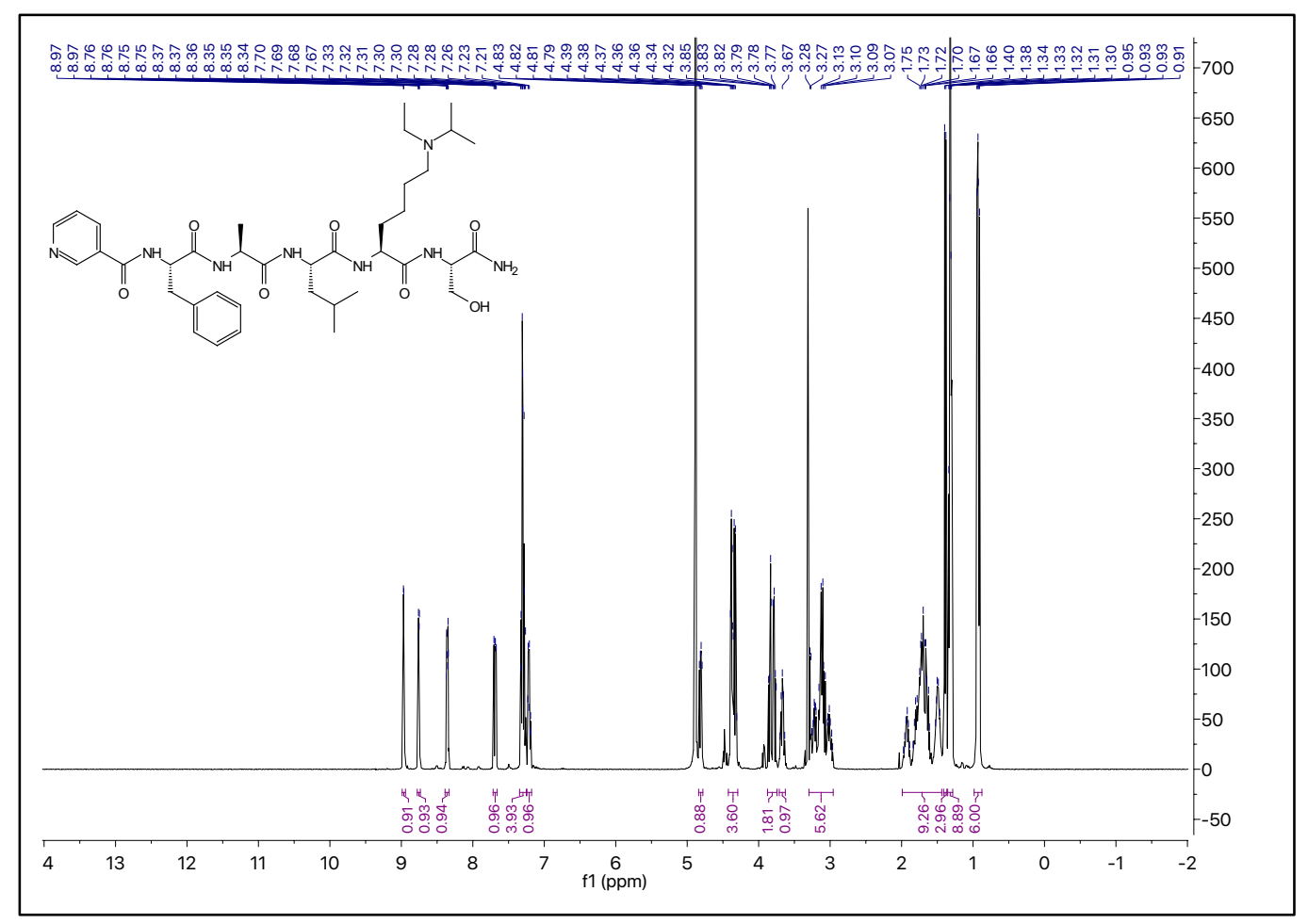

UNC6377

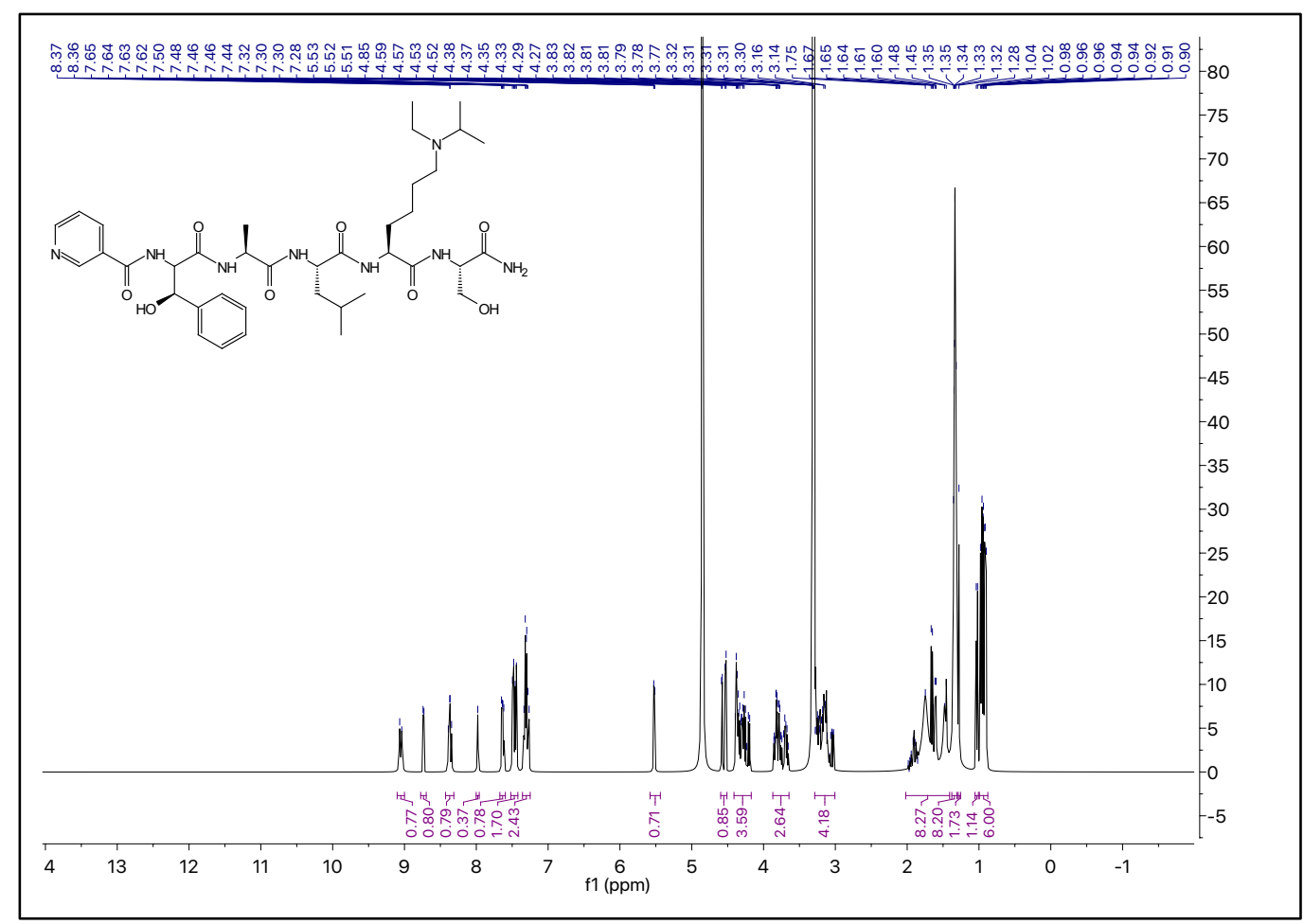

UNC6378 


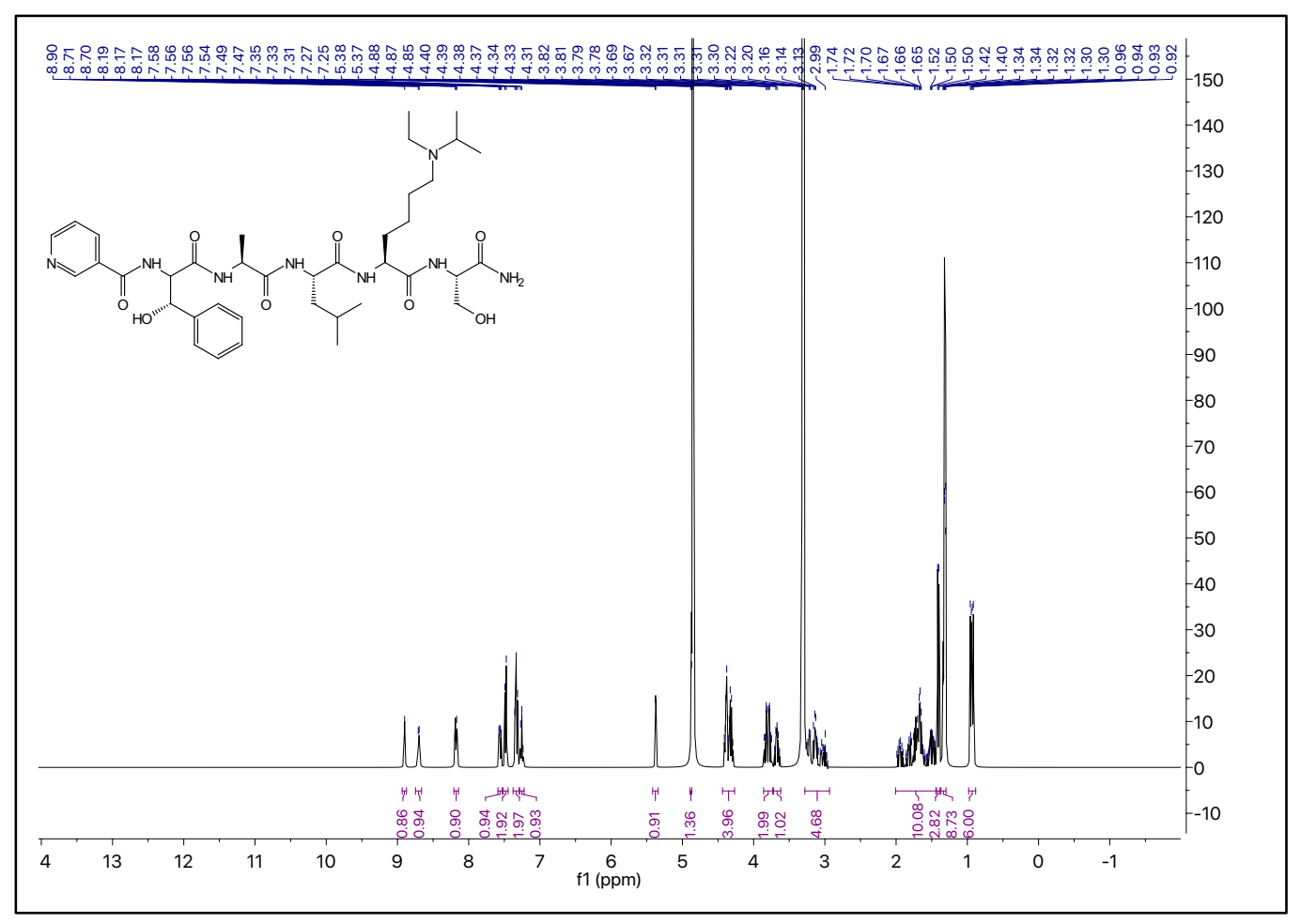

UNC6379

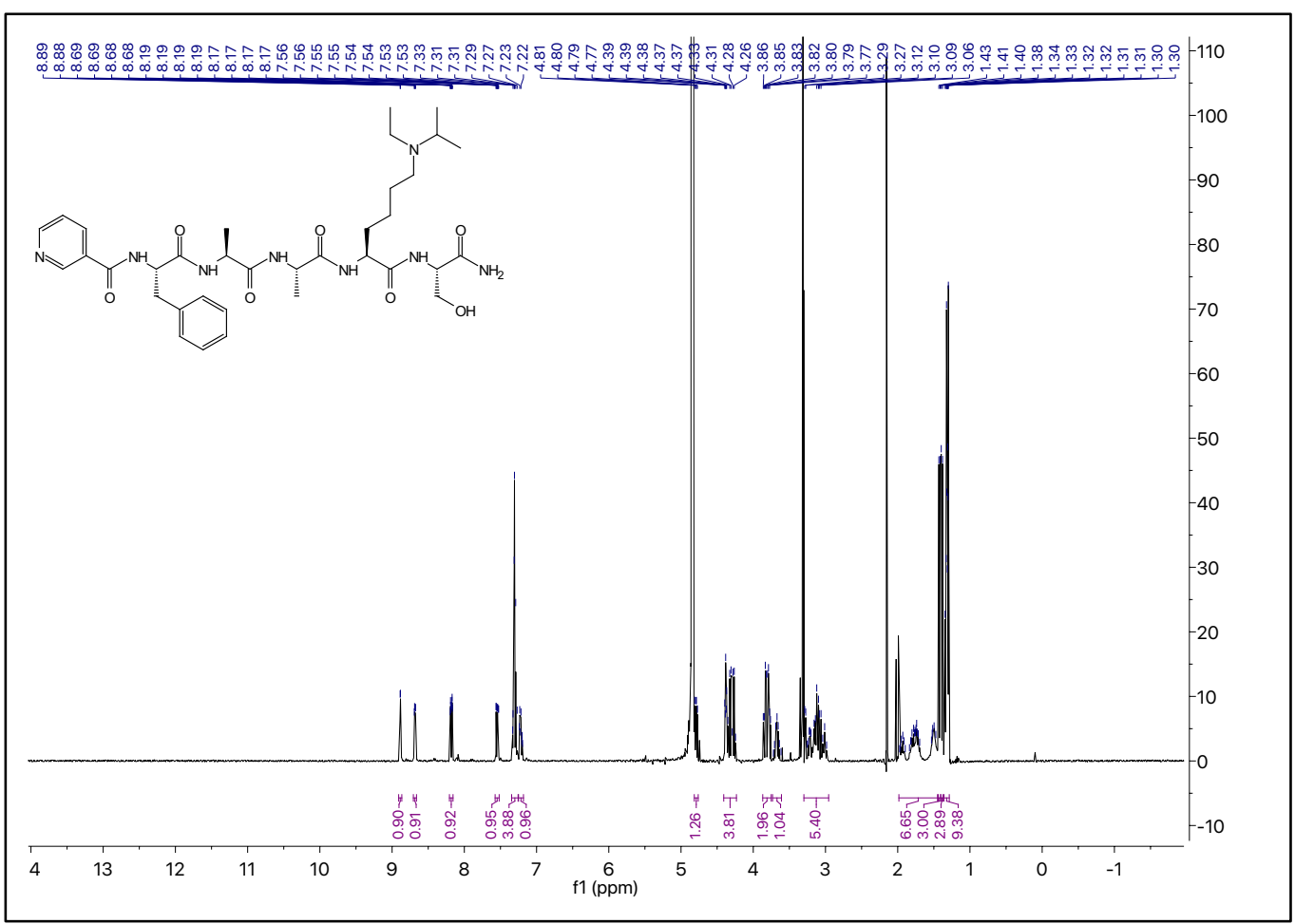

UNC6380 


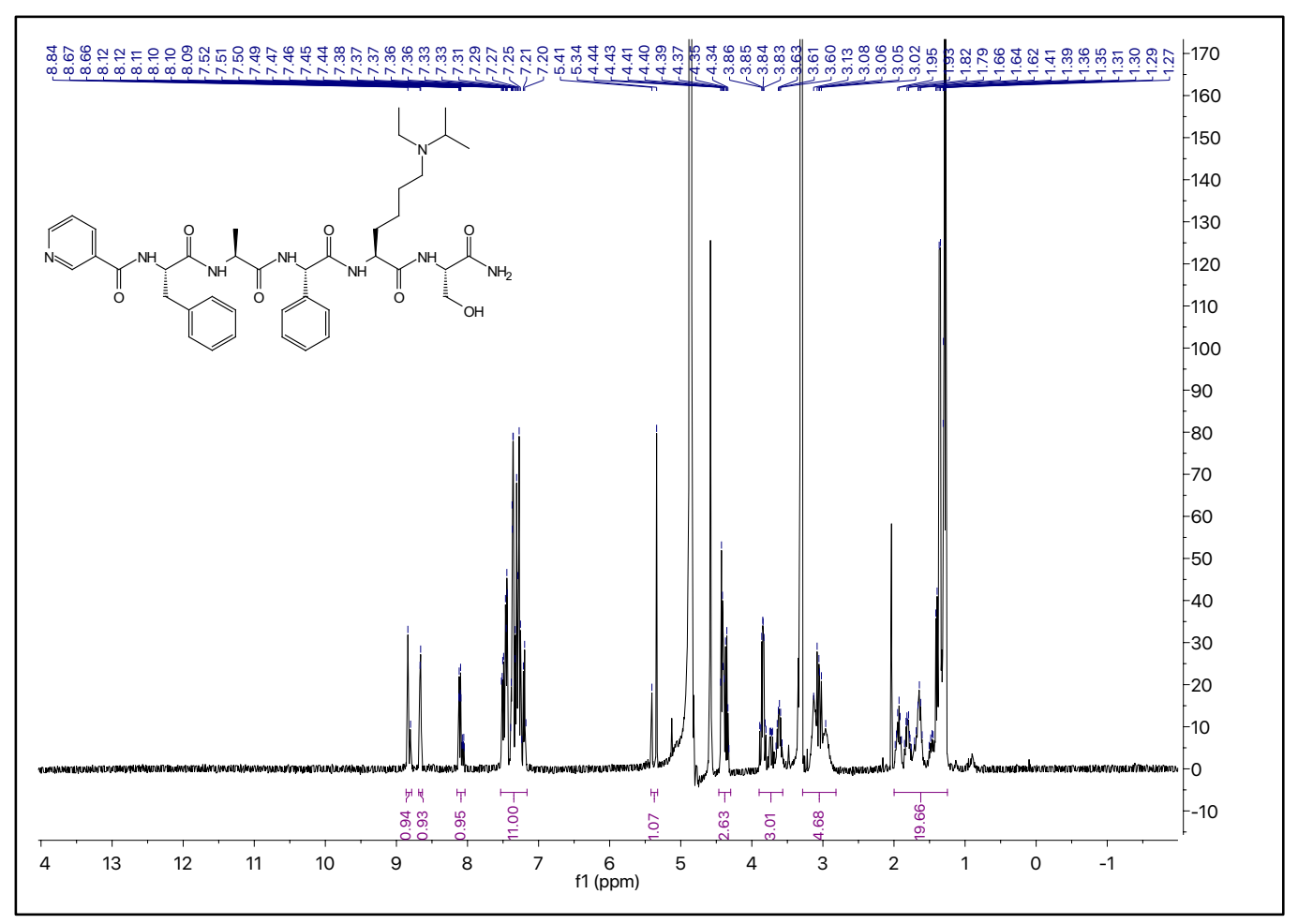

\section{UNC6381}

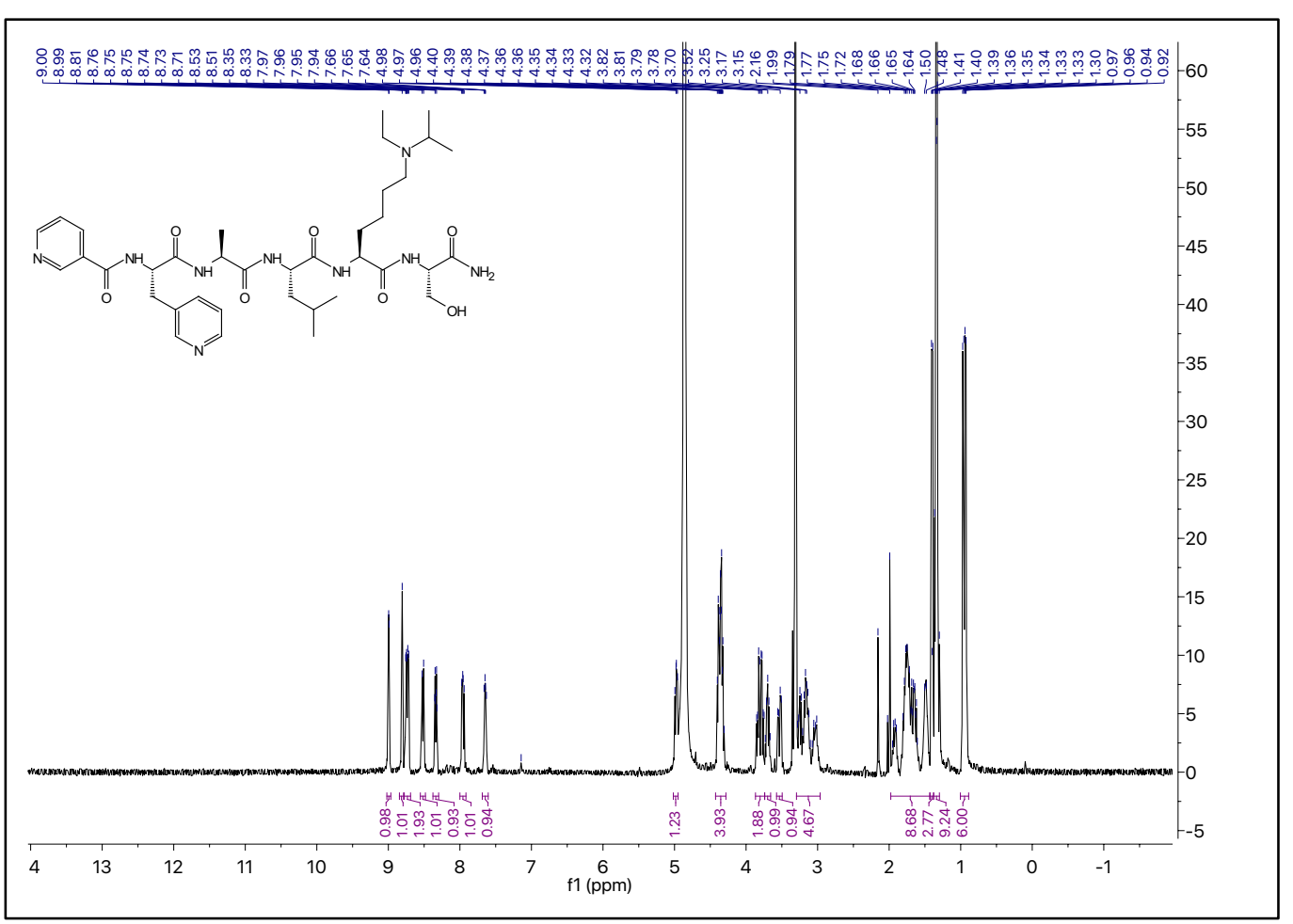

UNC6382 


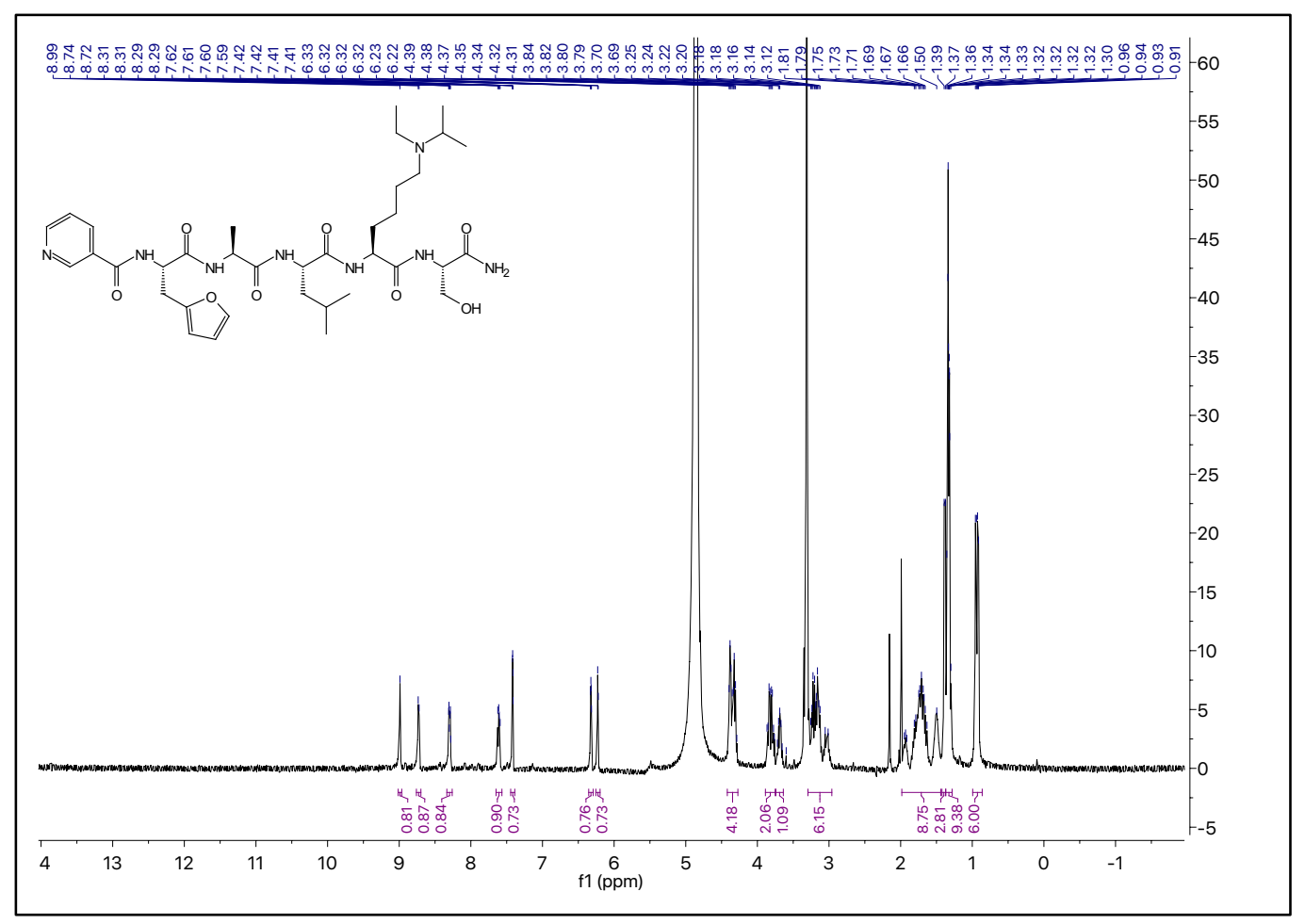

\section{UNC6383}

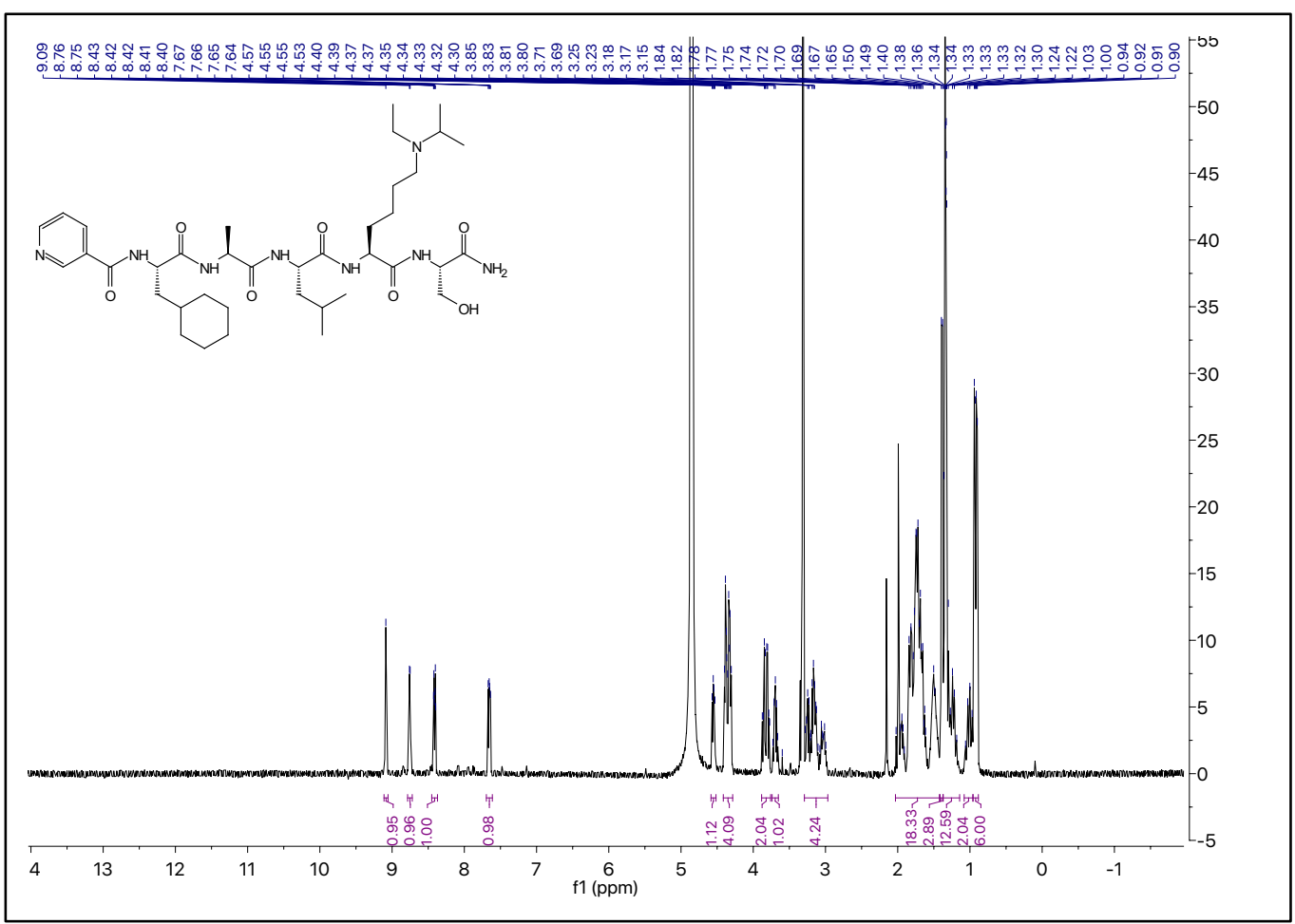

UNC6384 


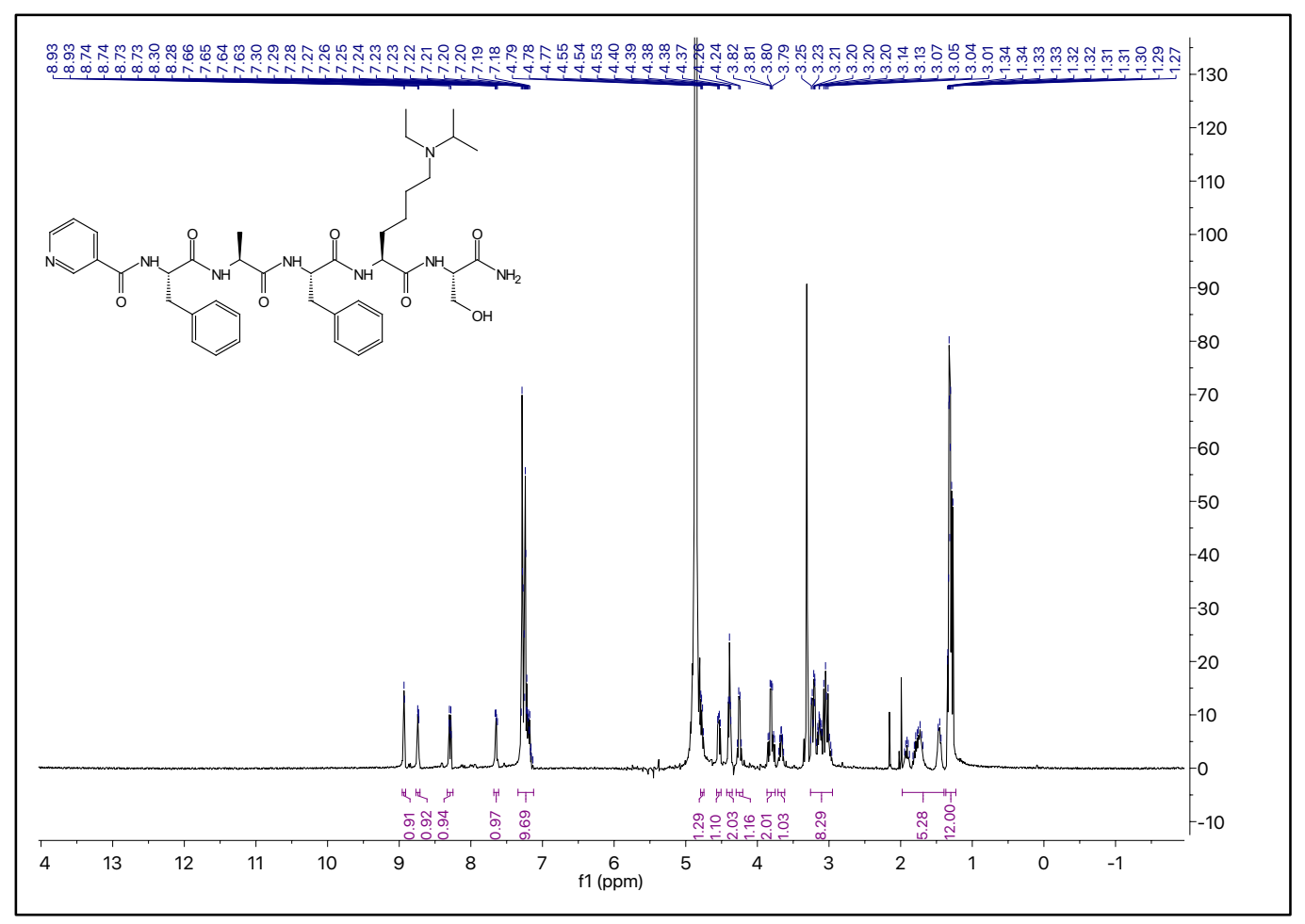

UNC6386

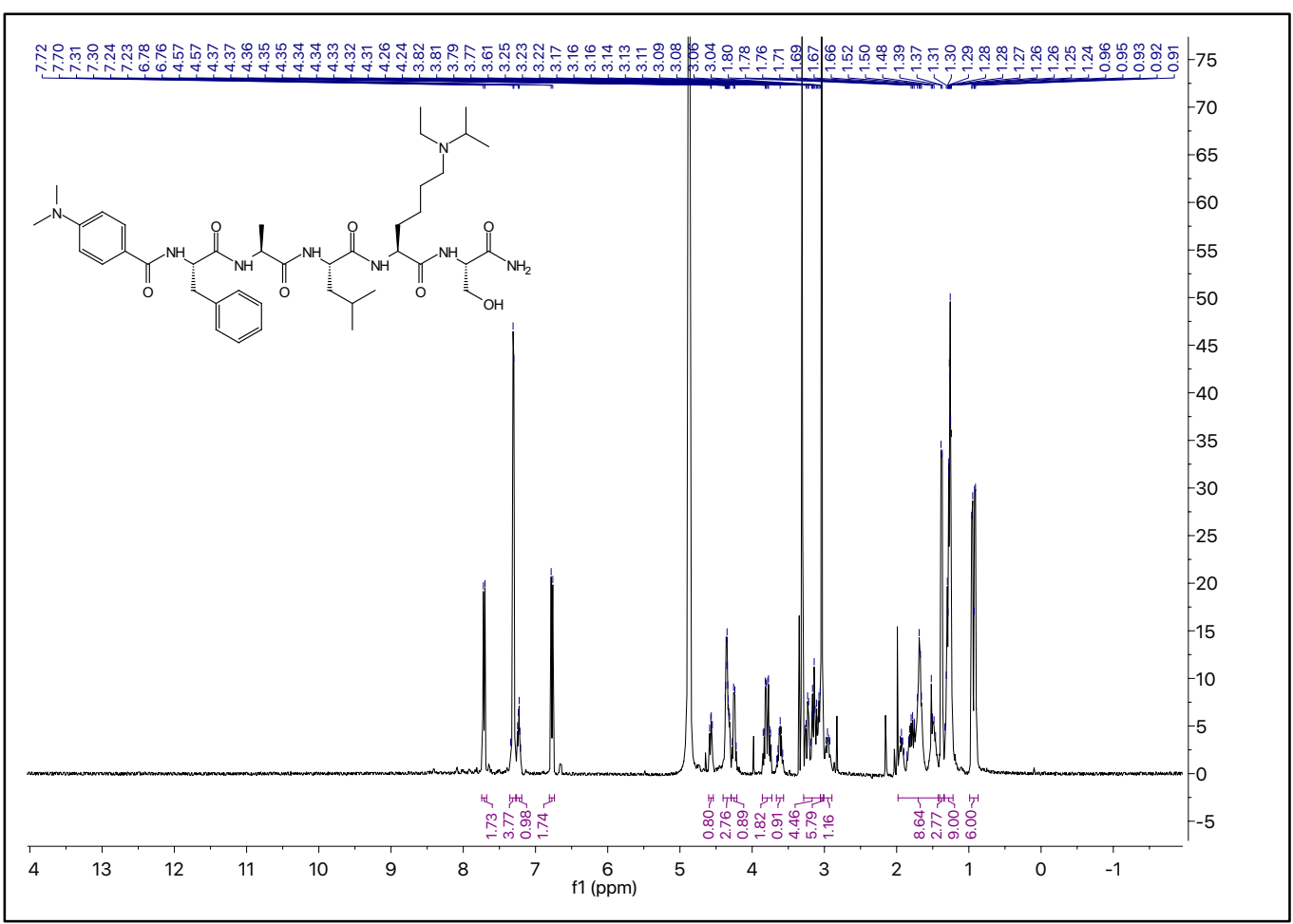




\section{UNC6387}

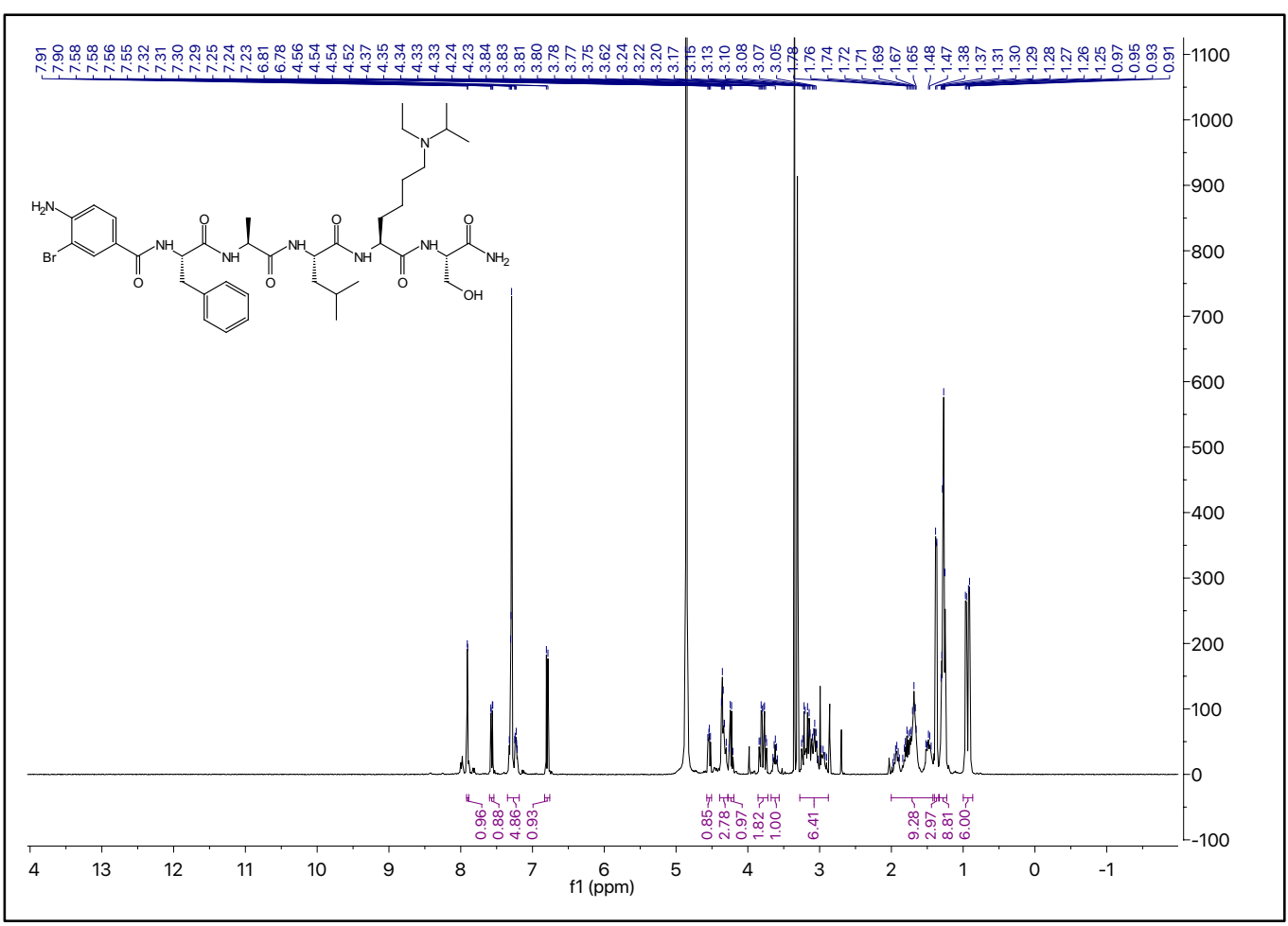

\section{UNC6389}

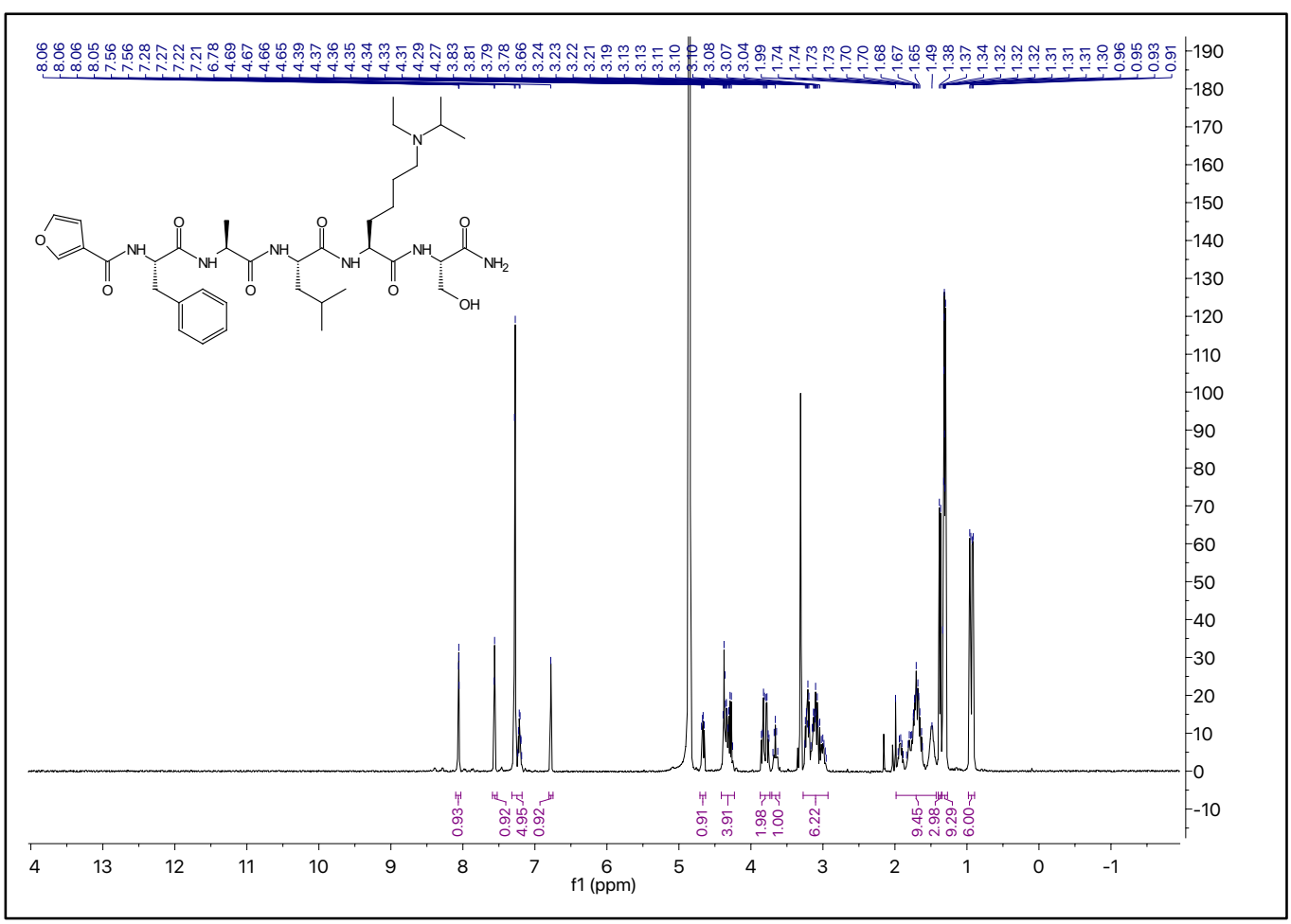

\section{UNC6390}




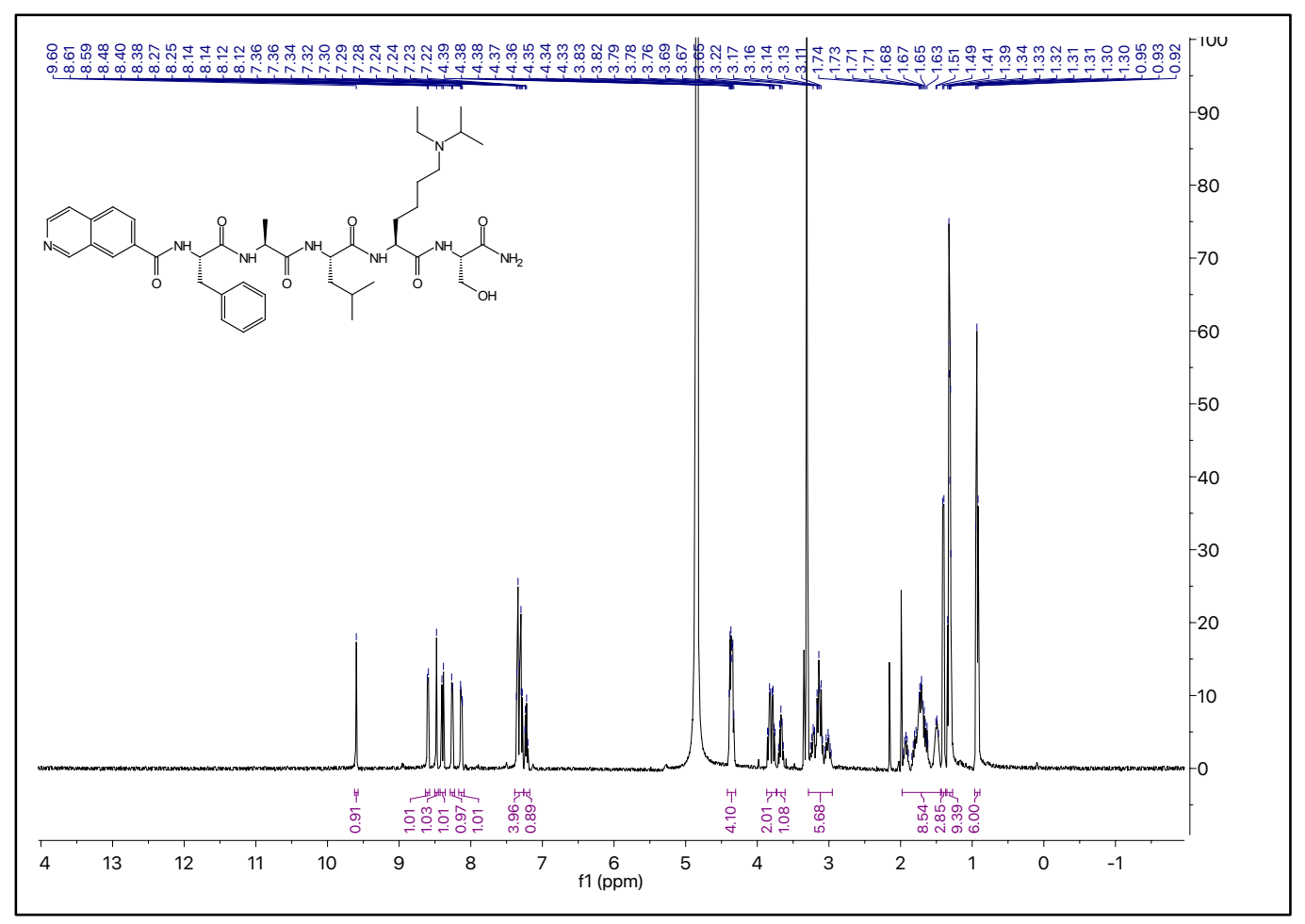

UNC6391

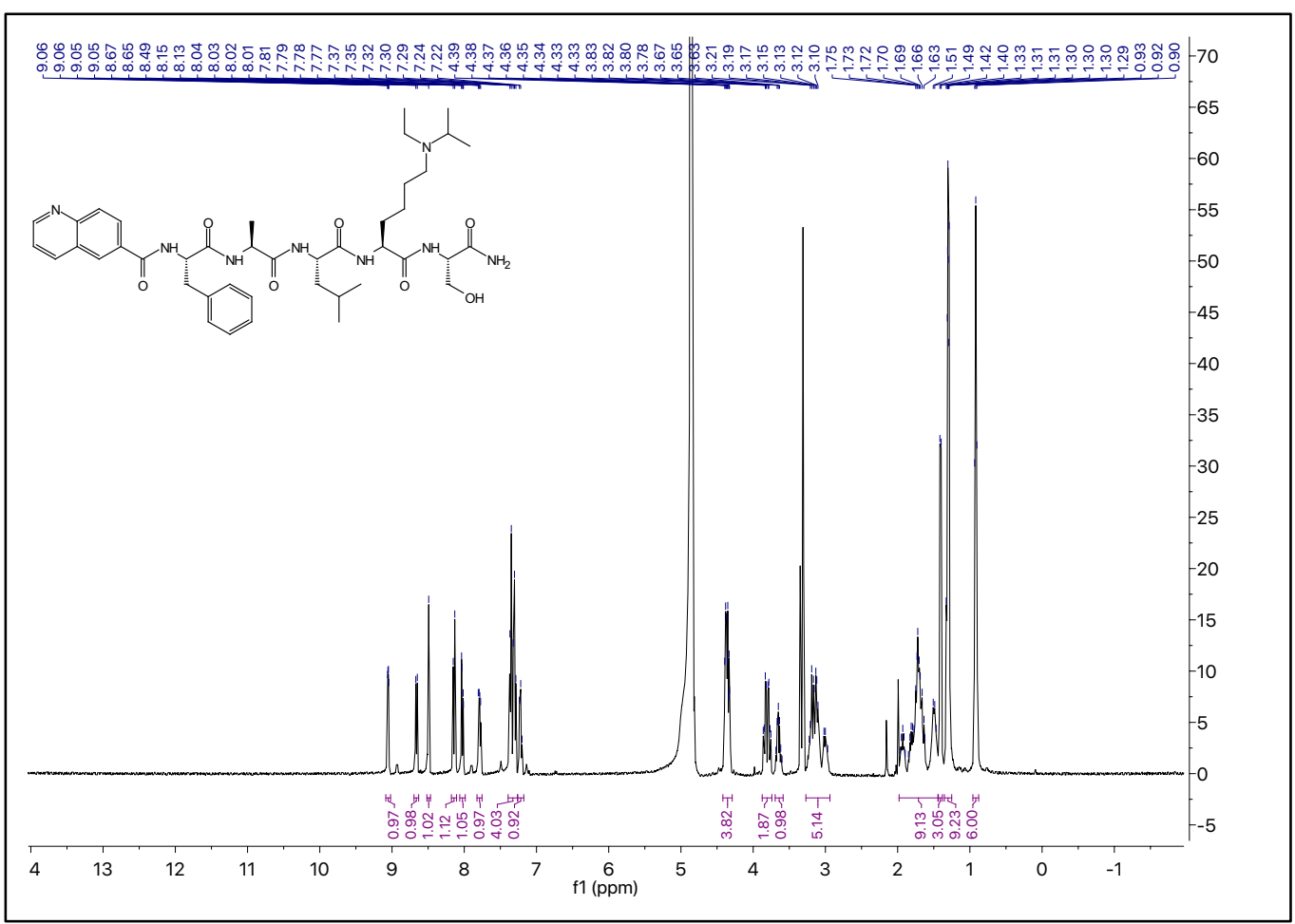

UNC6392 


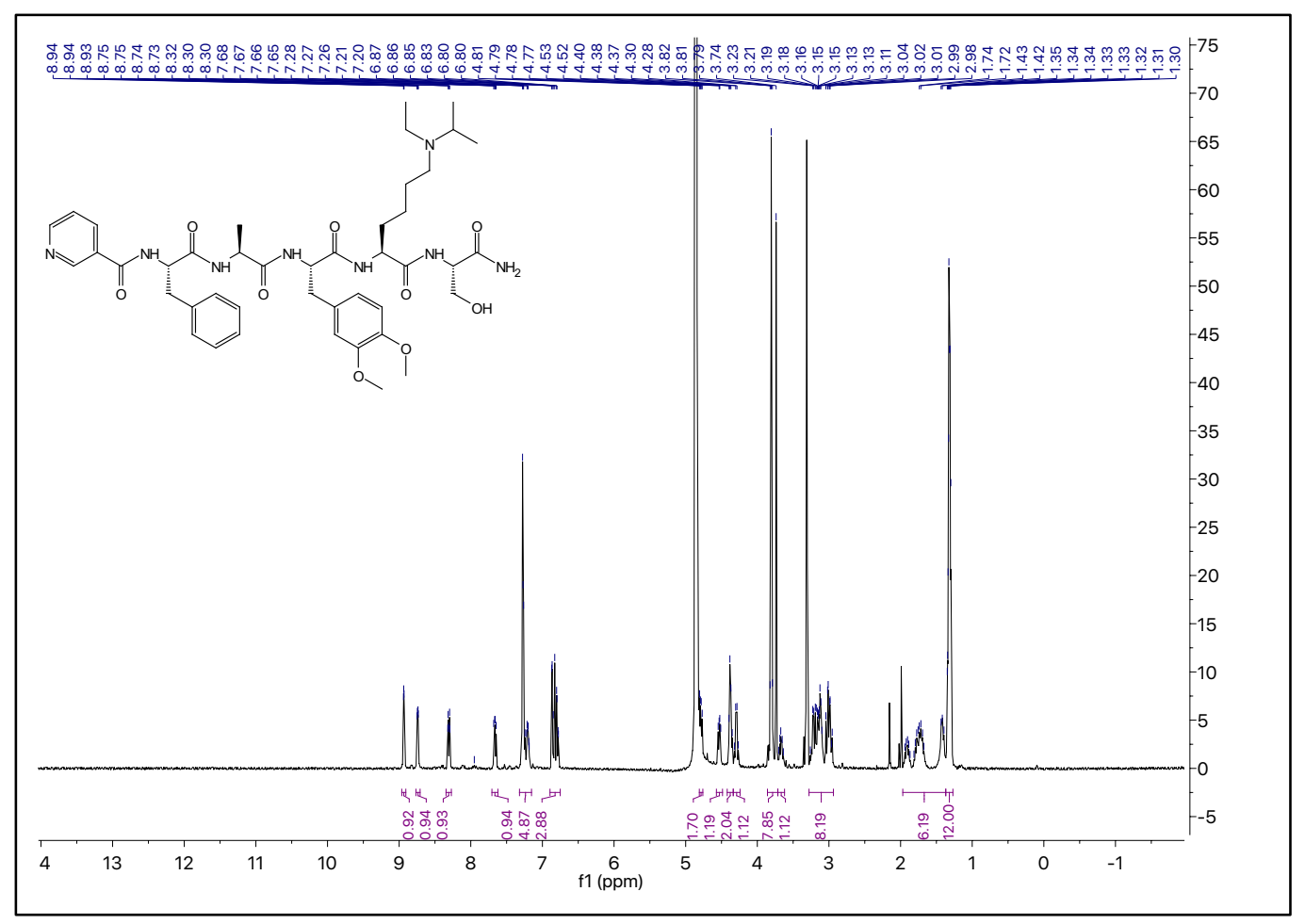

UNC6393

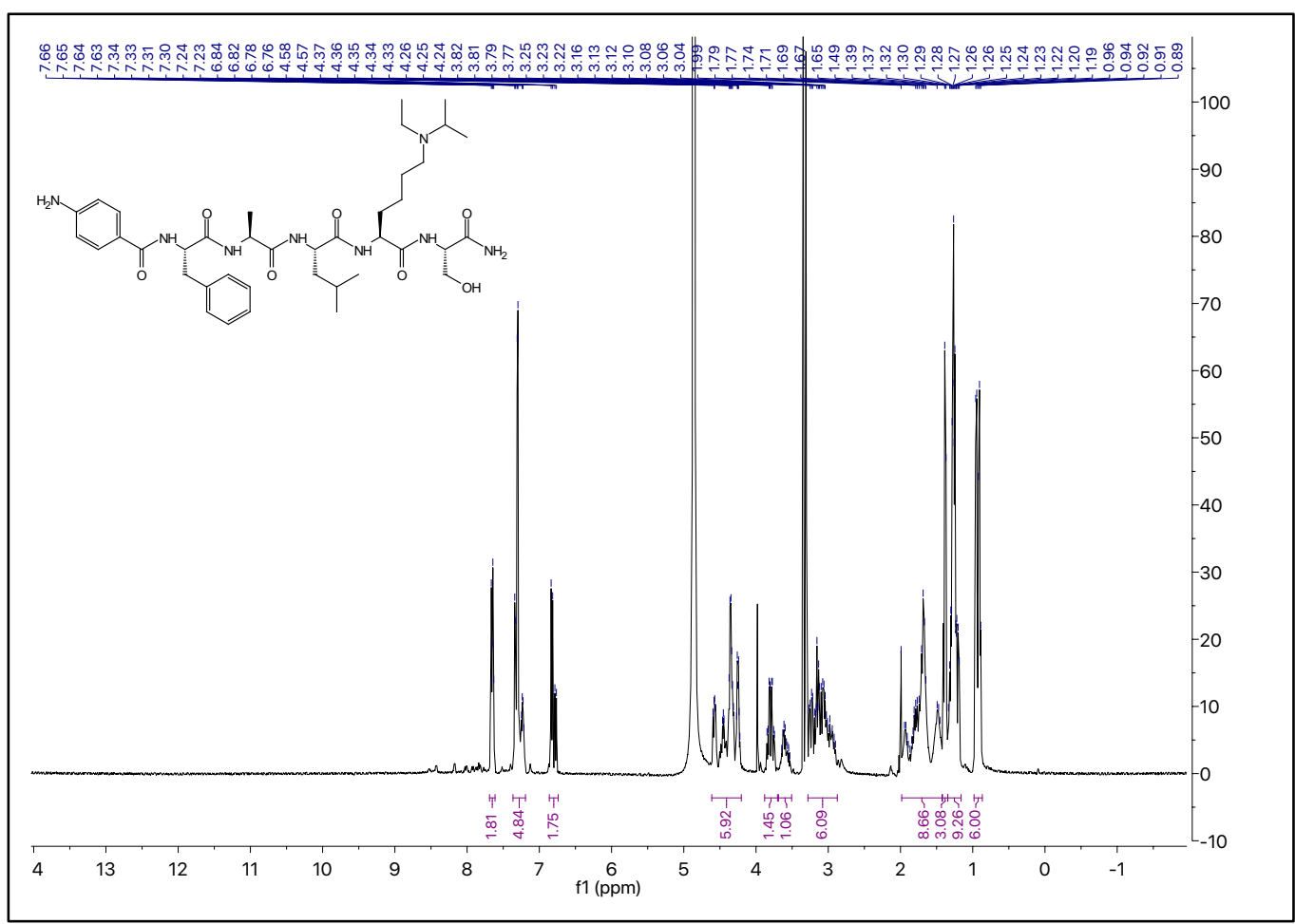

UNC6394 


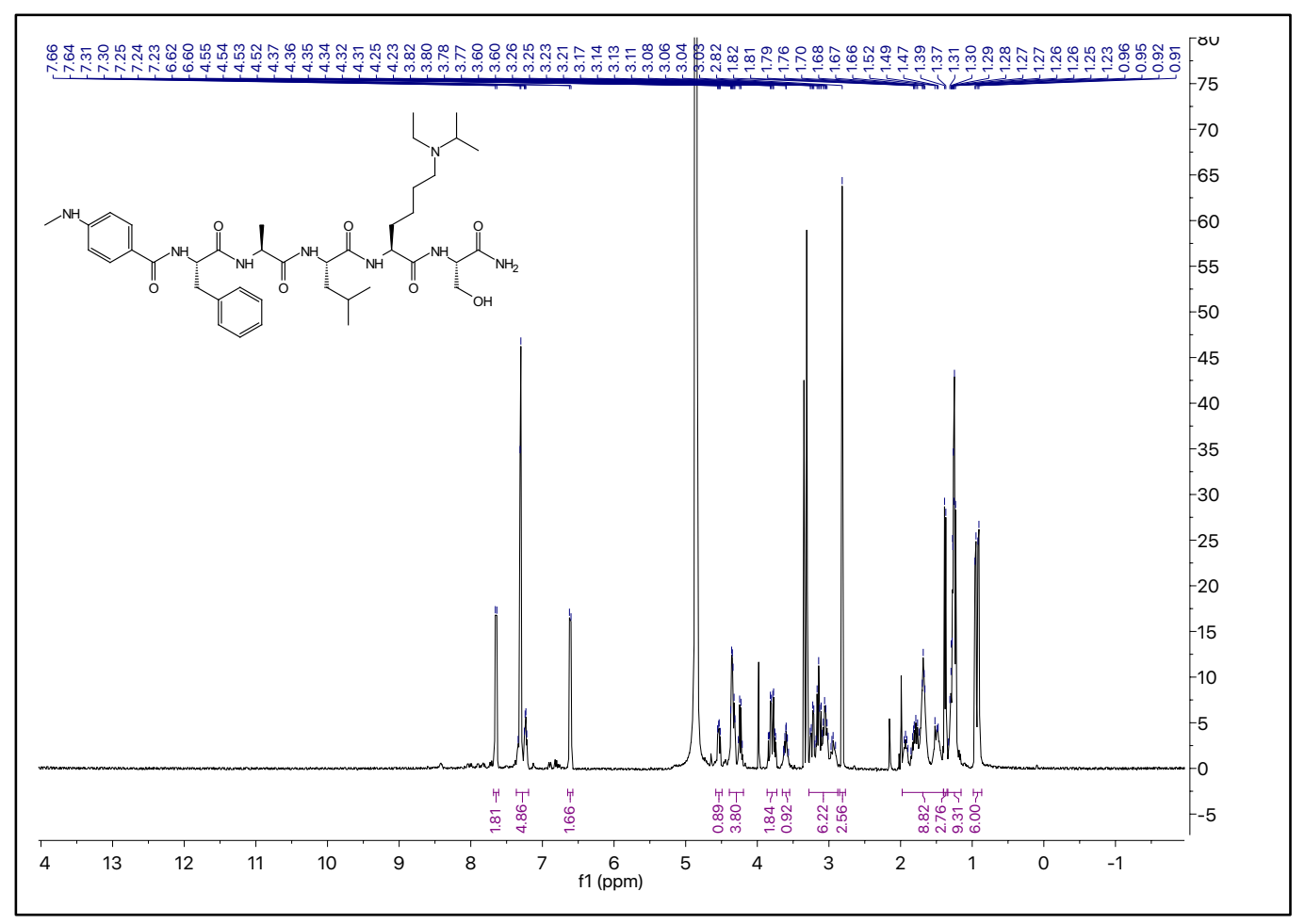

\section{UNC6865}

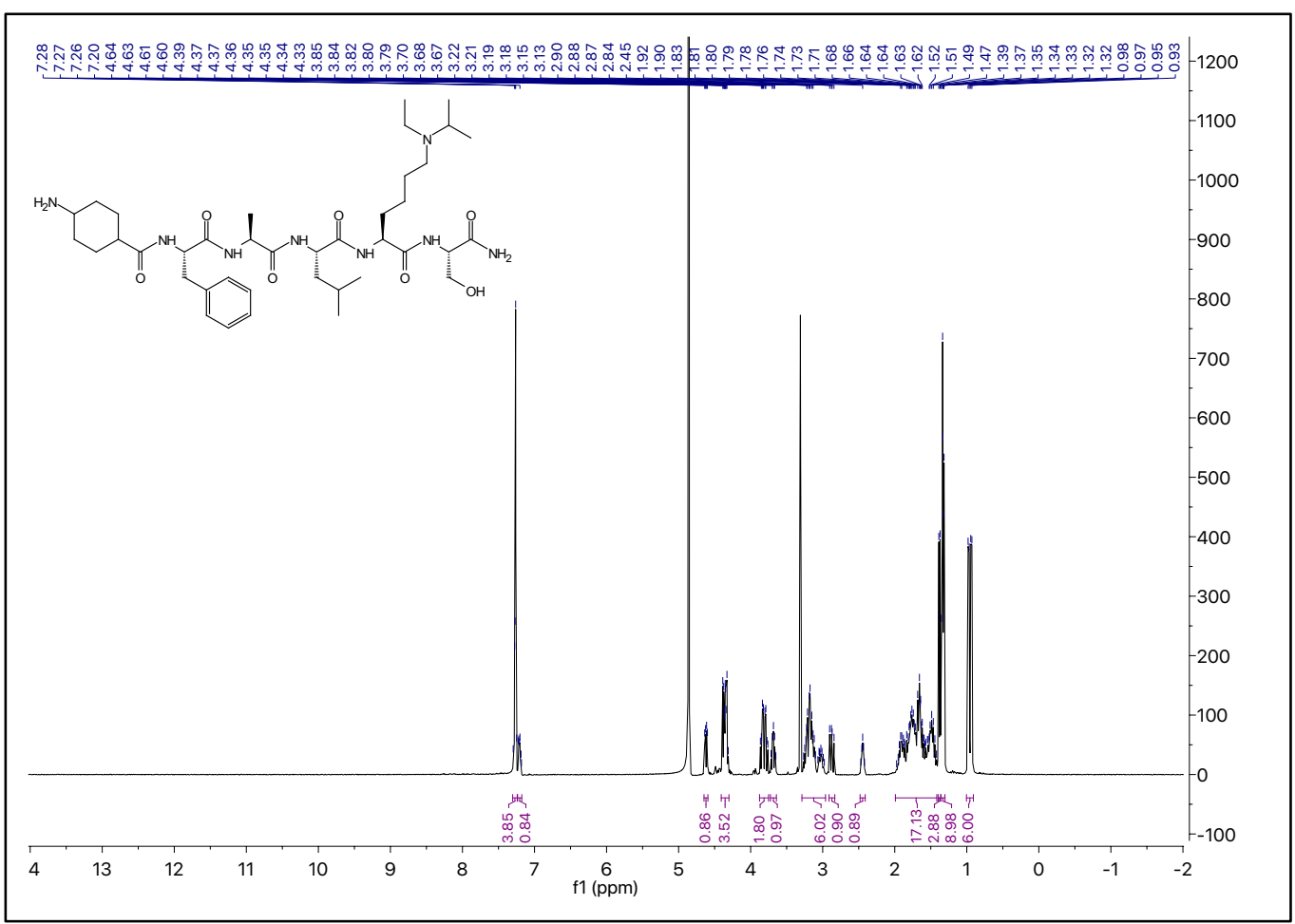

UNC6866 


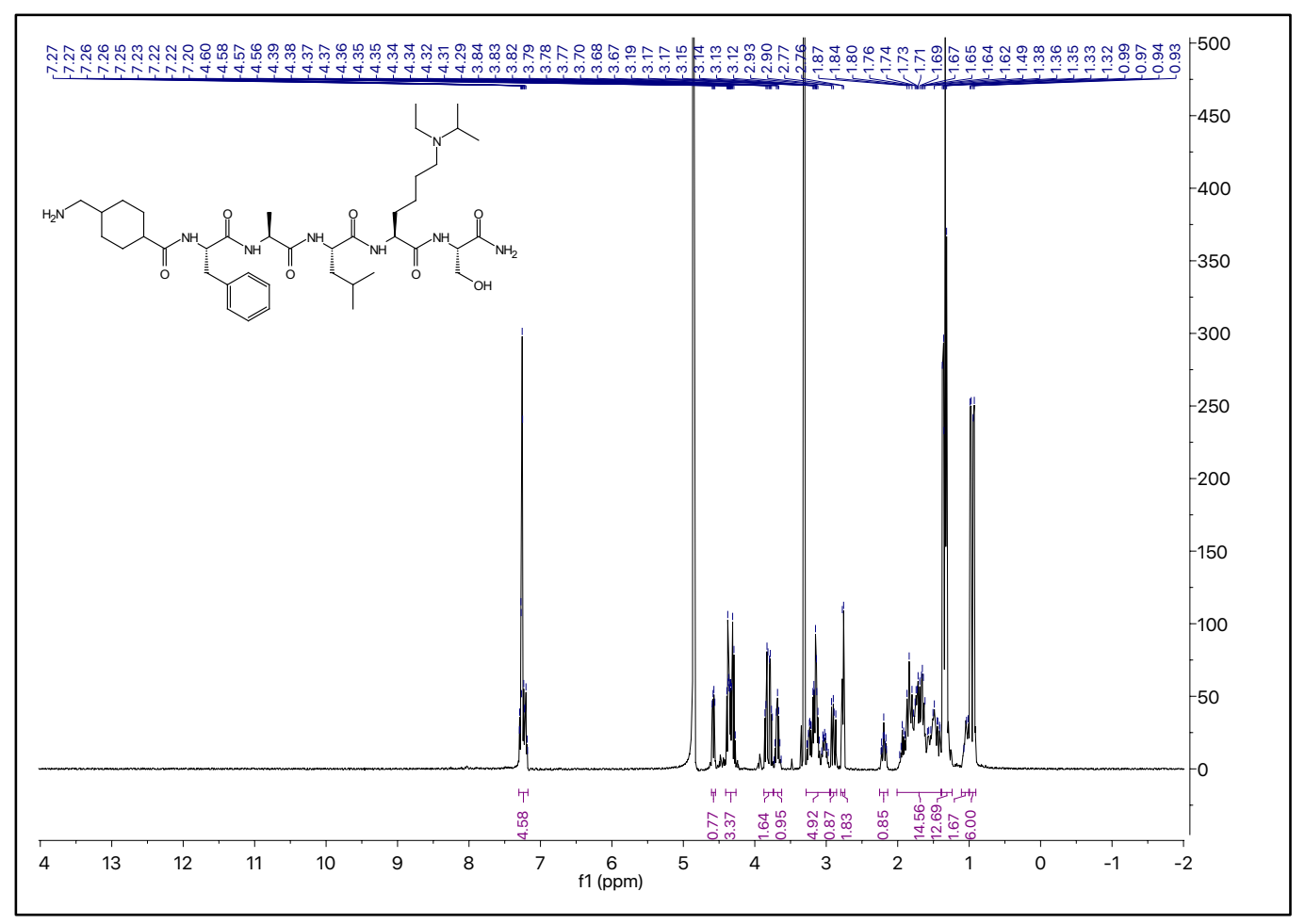

UNC6867

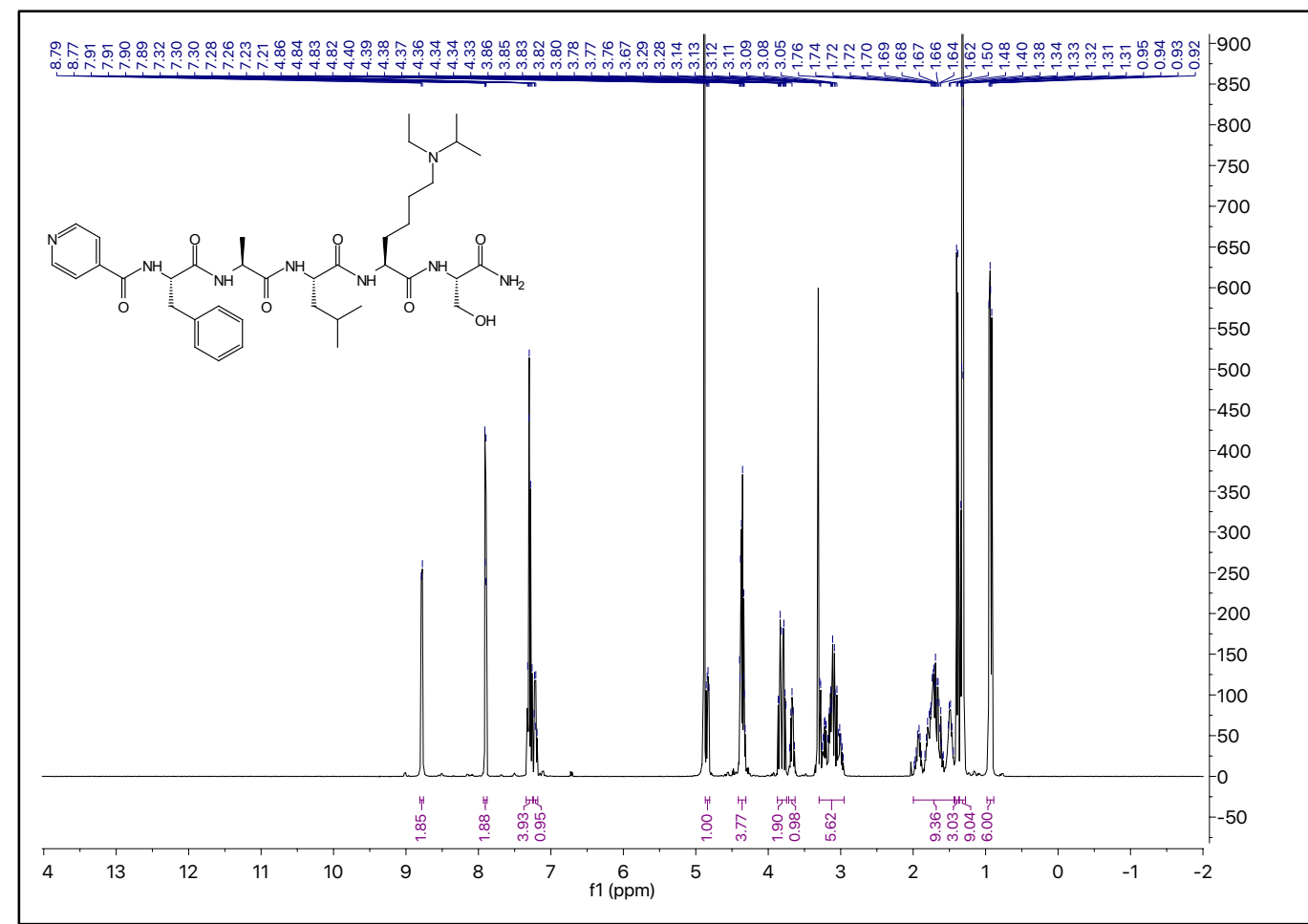

UNC6868 


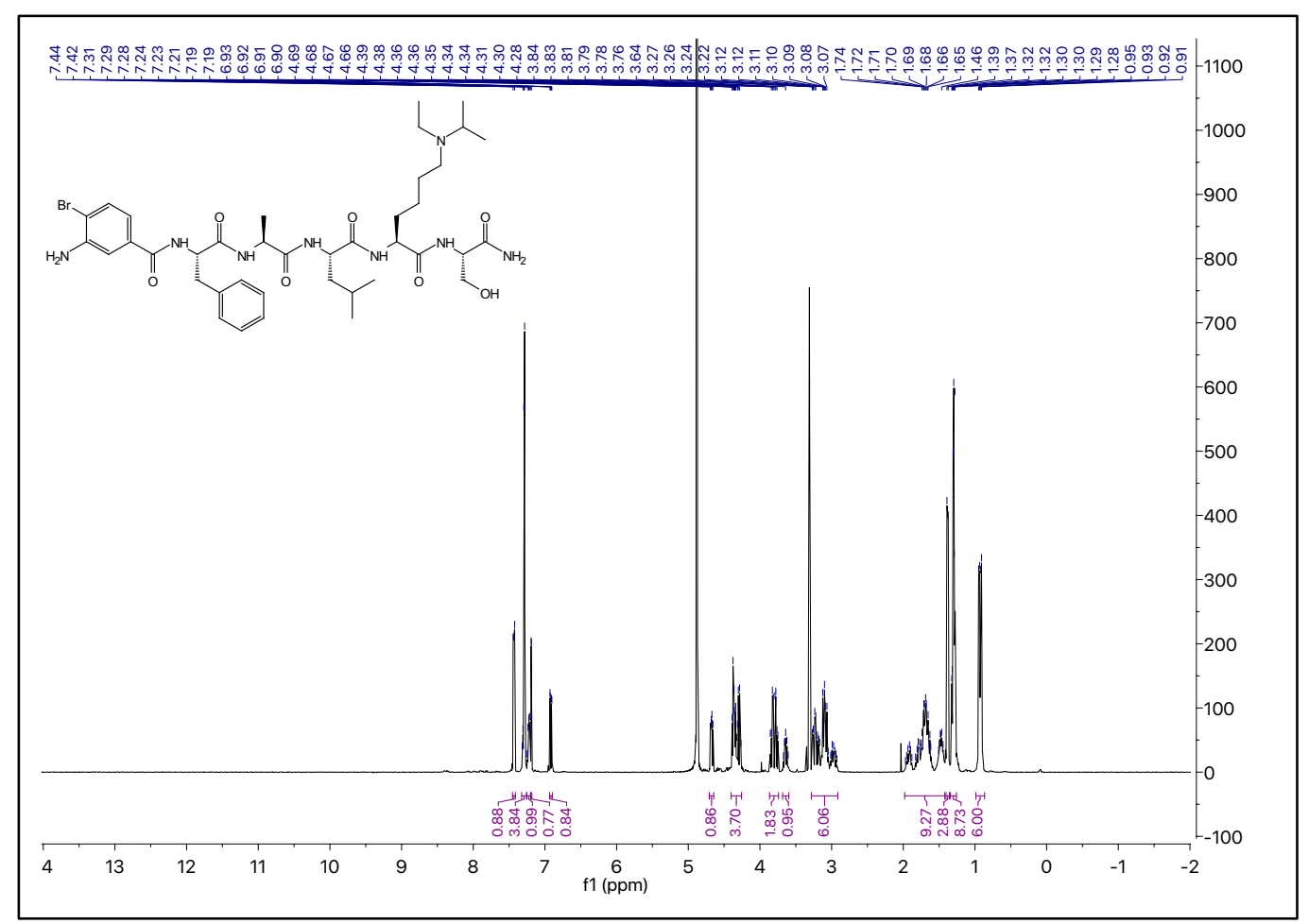

UNC7047

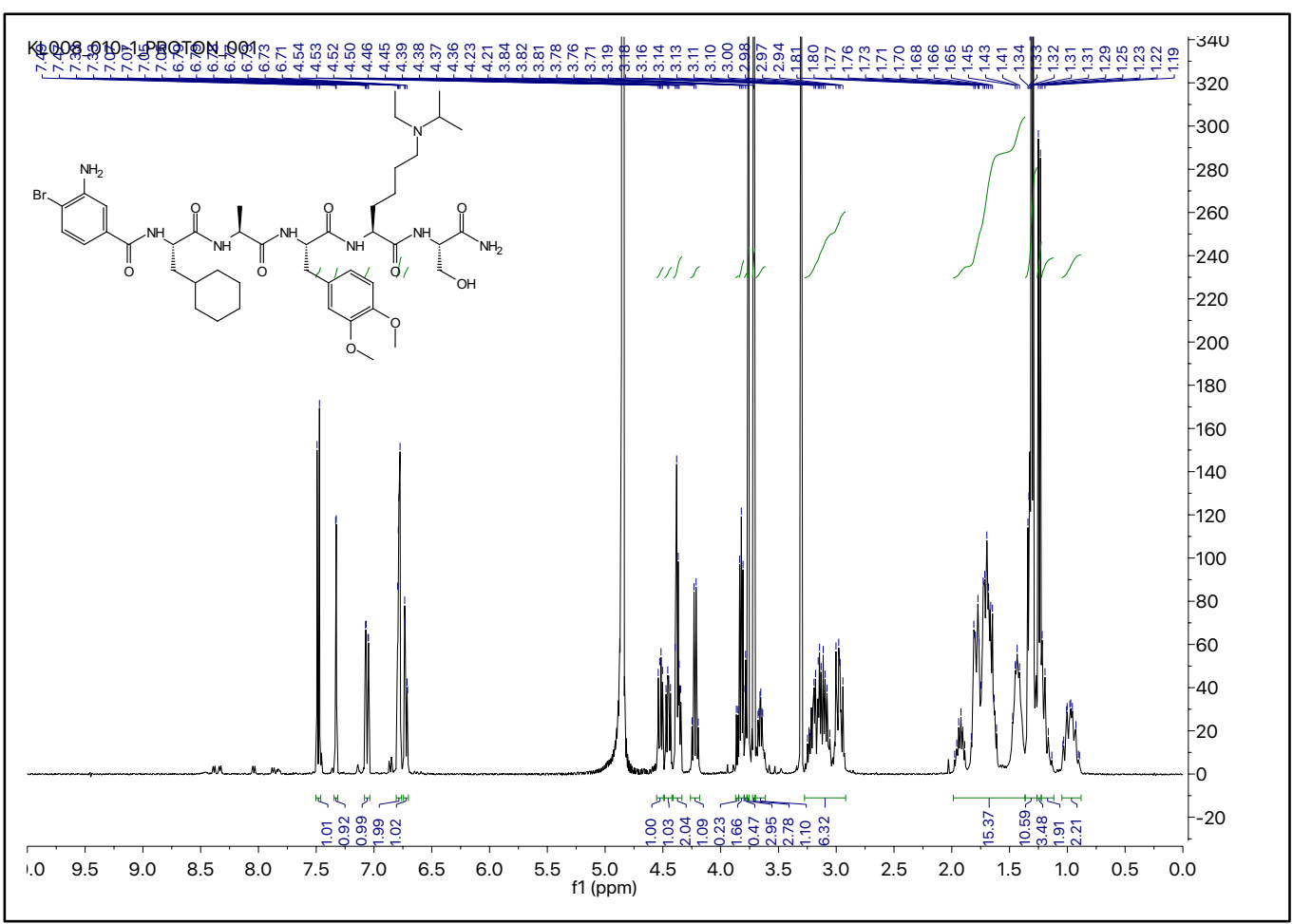

Intermediate 1 


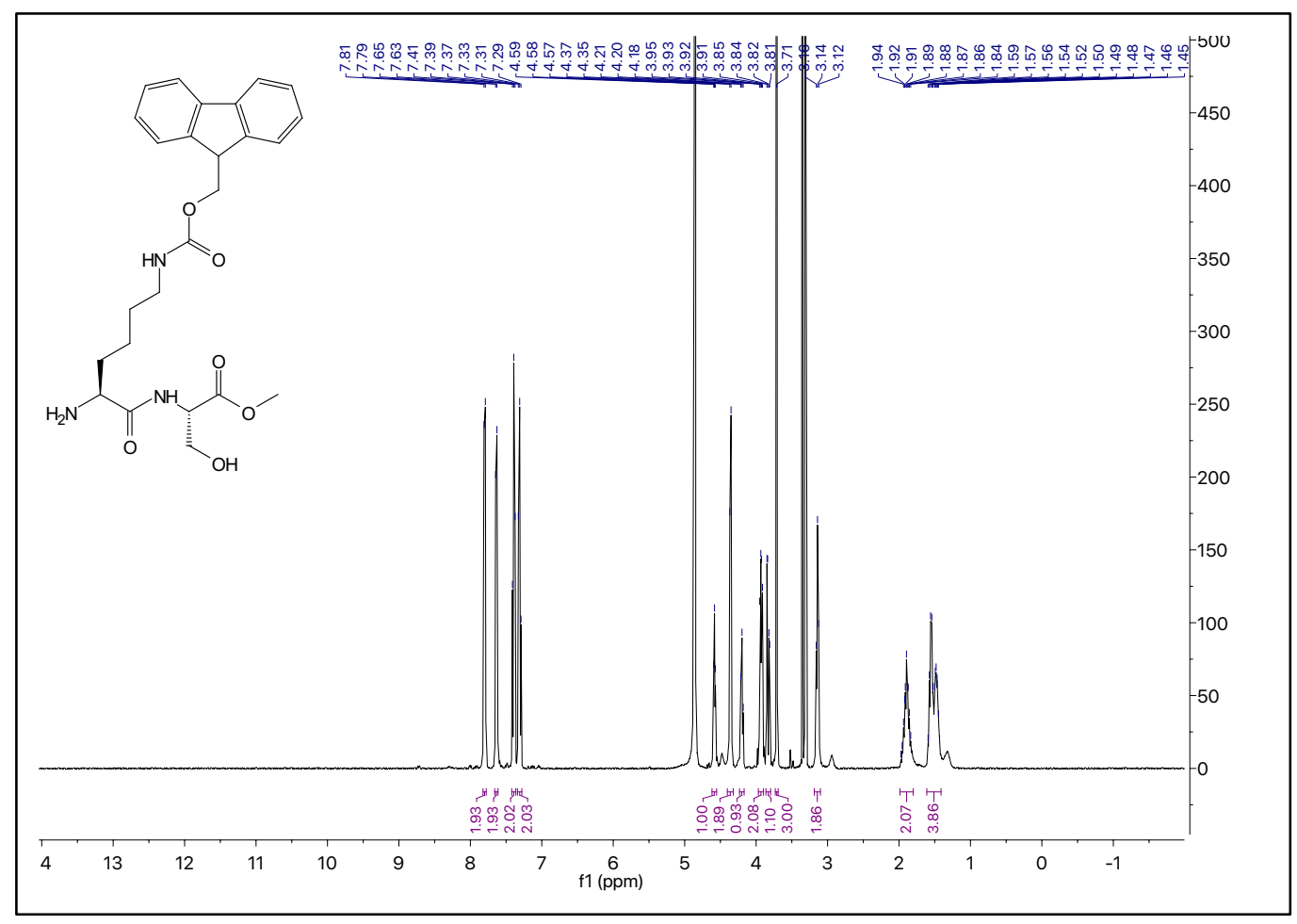

\section{Intermediate 2}

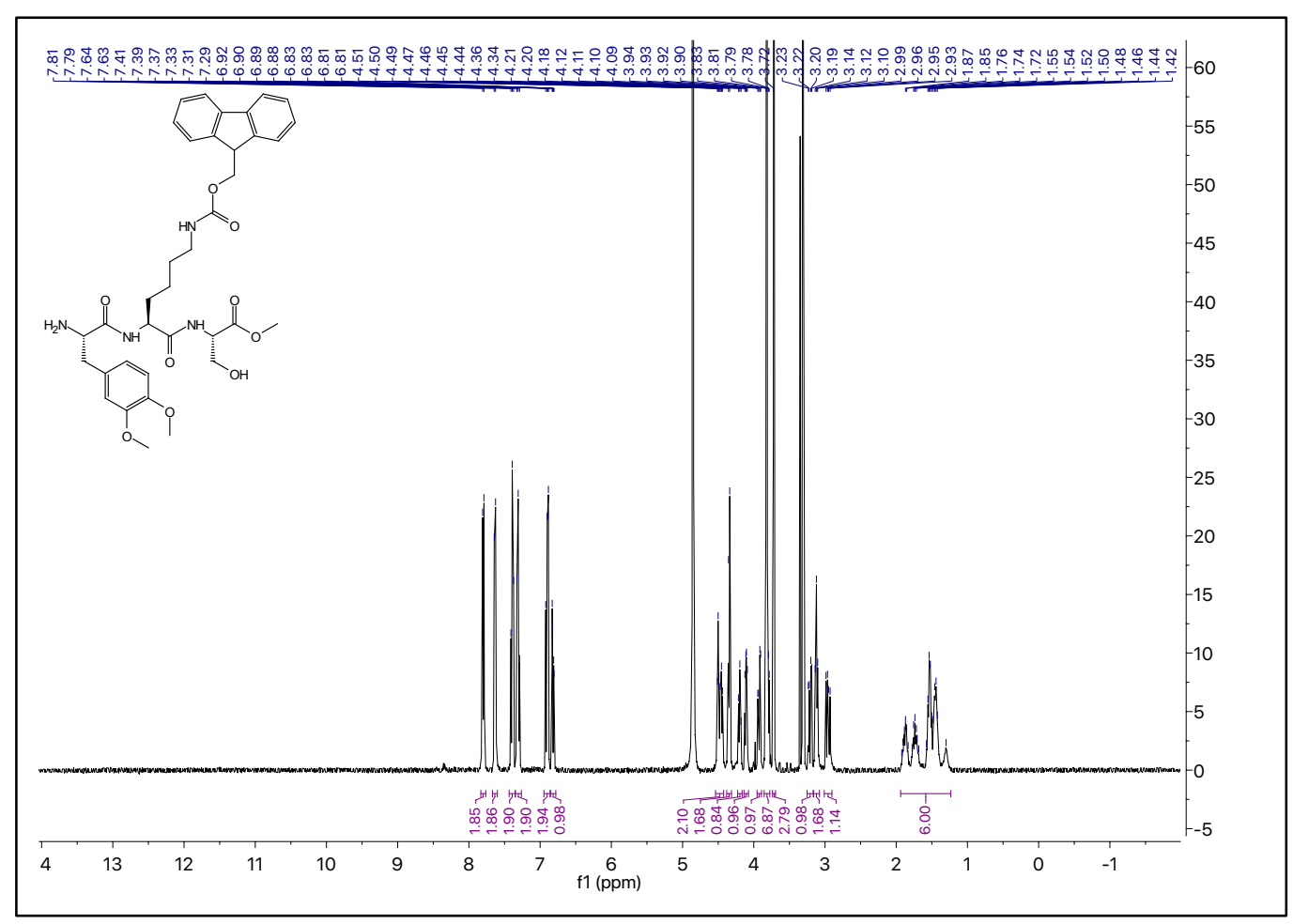

Intermediate 3 


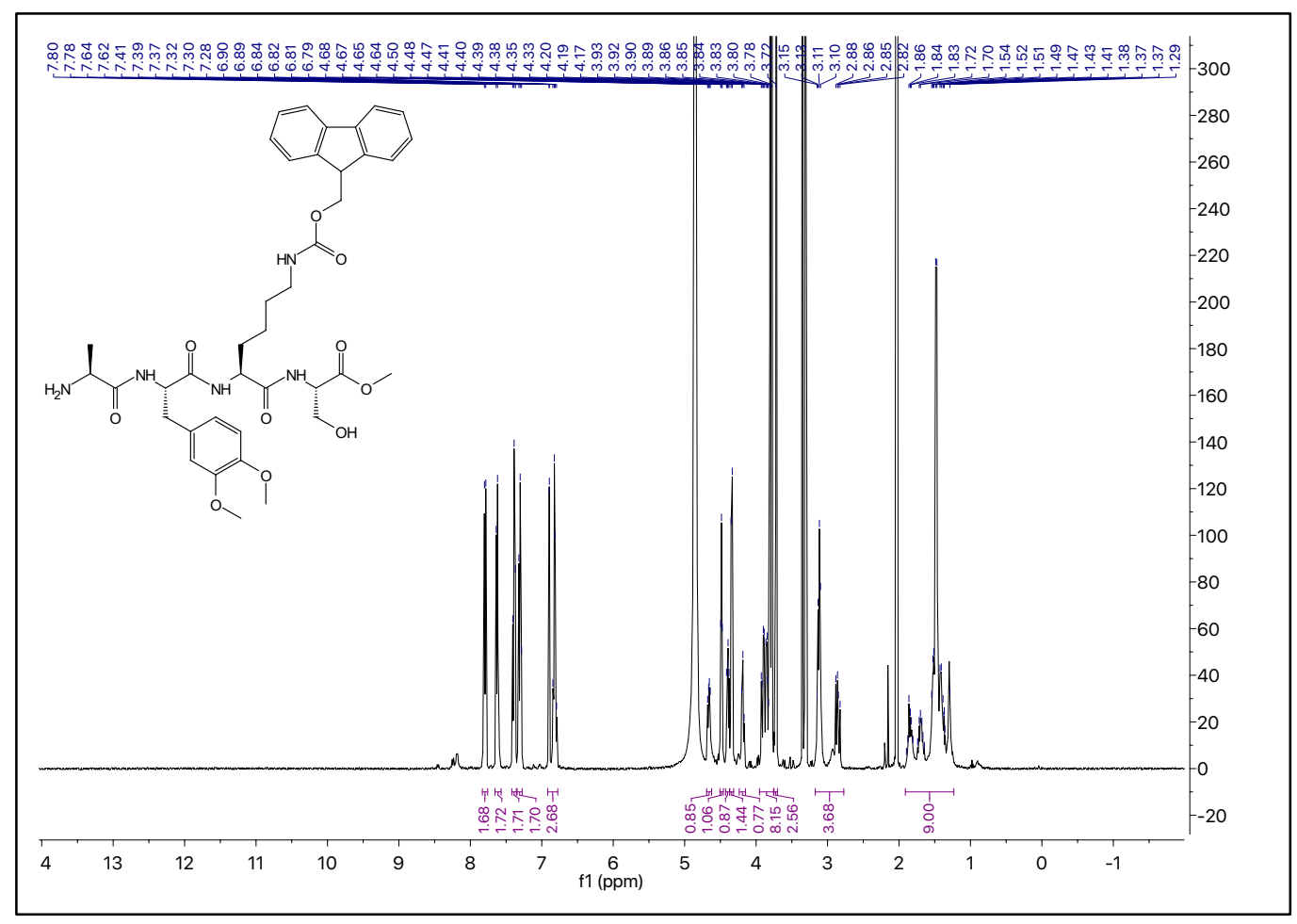

\section{Intermediate 4}

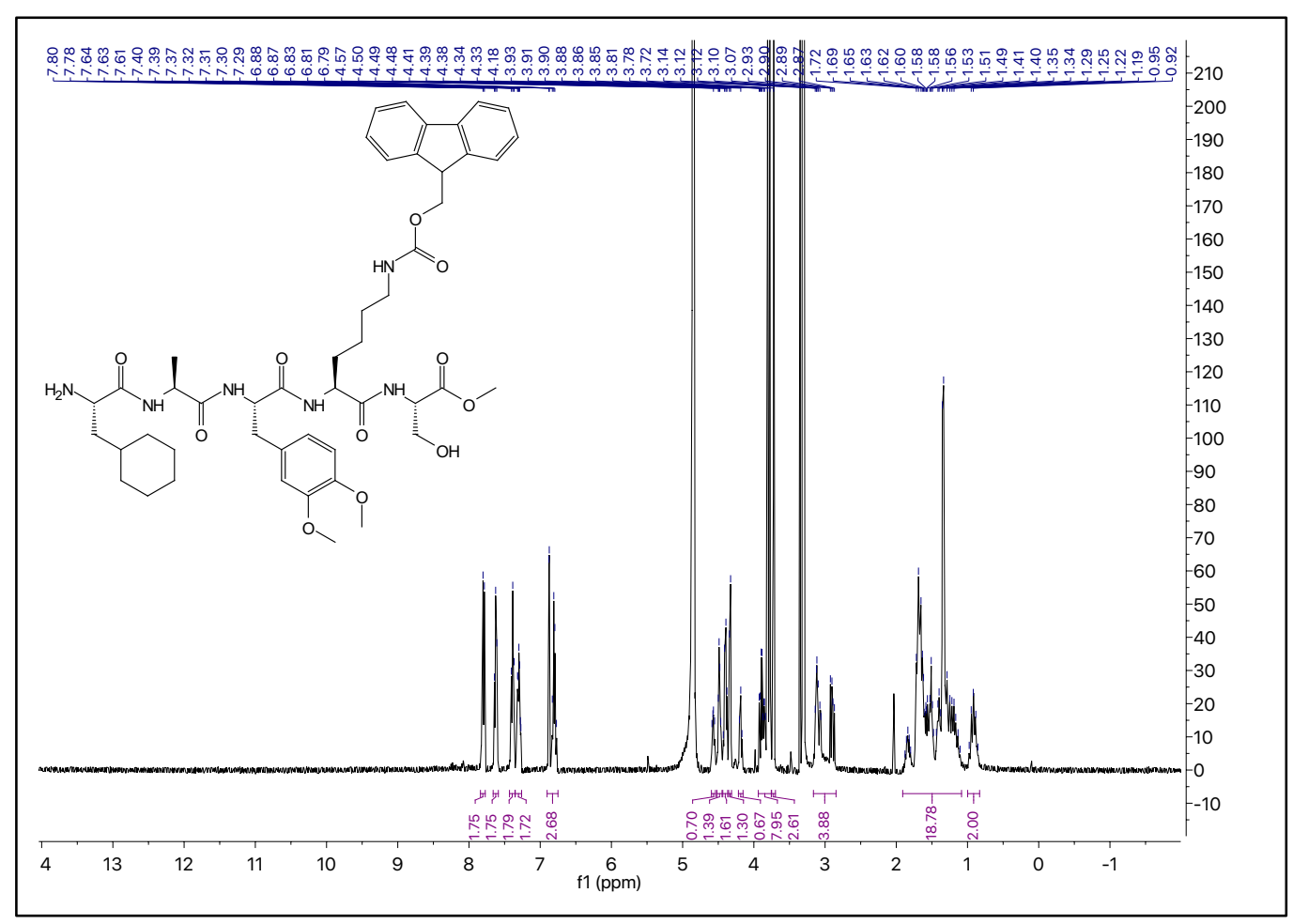

Intermediate 5 


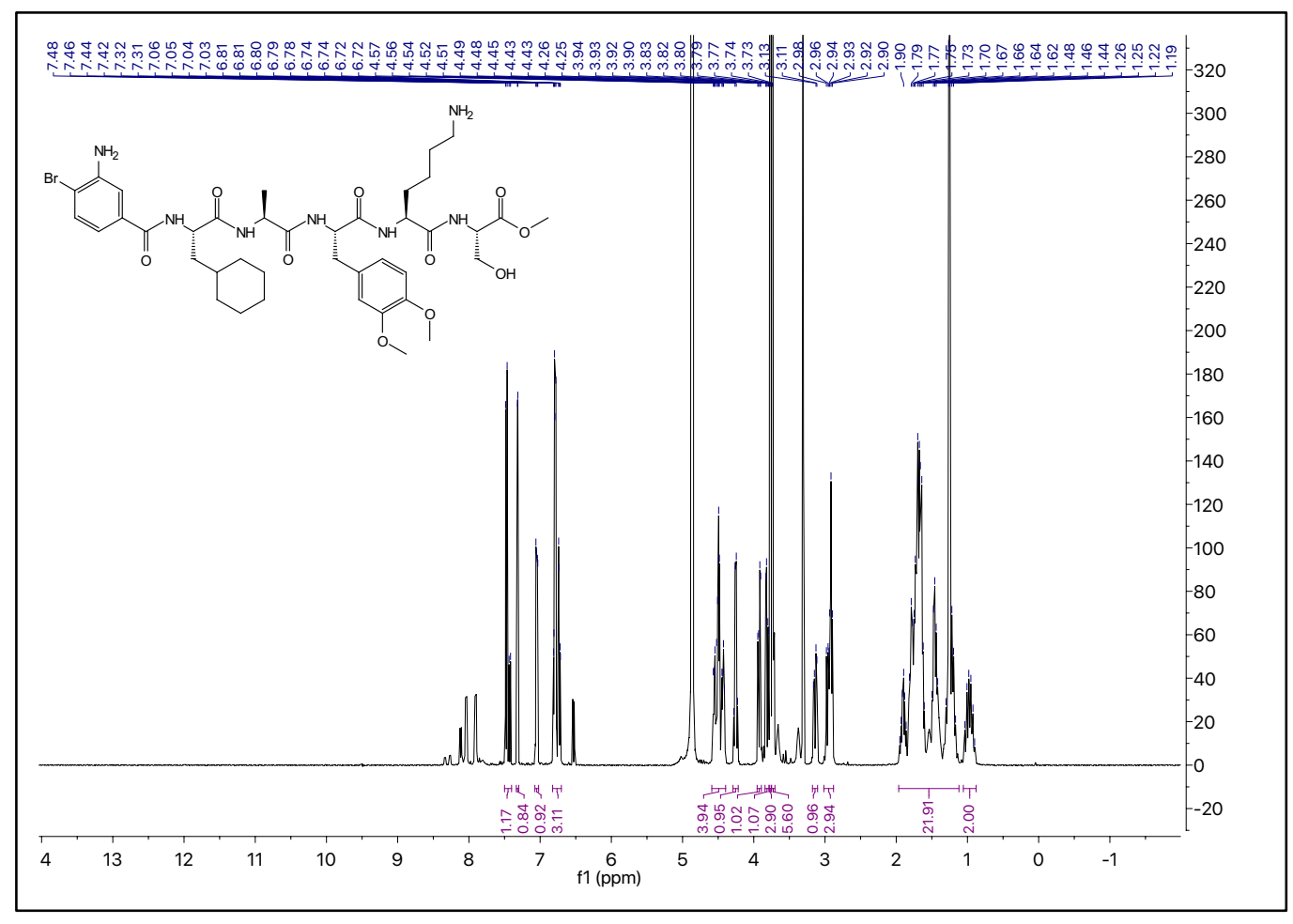

UNC7560

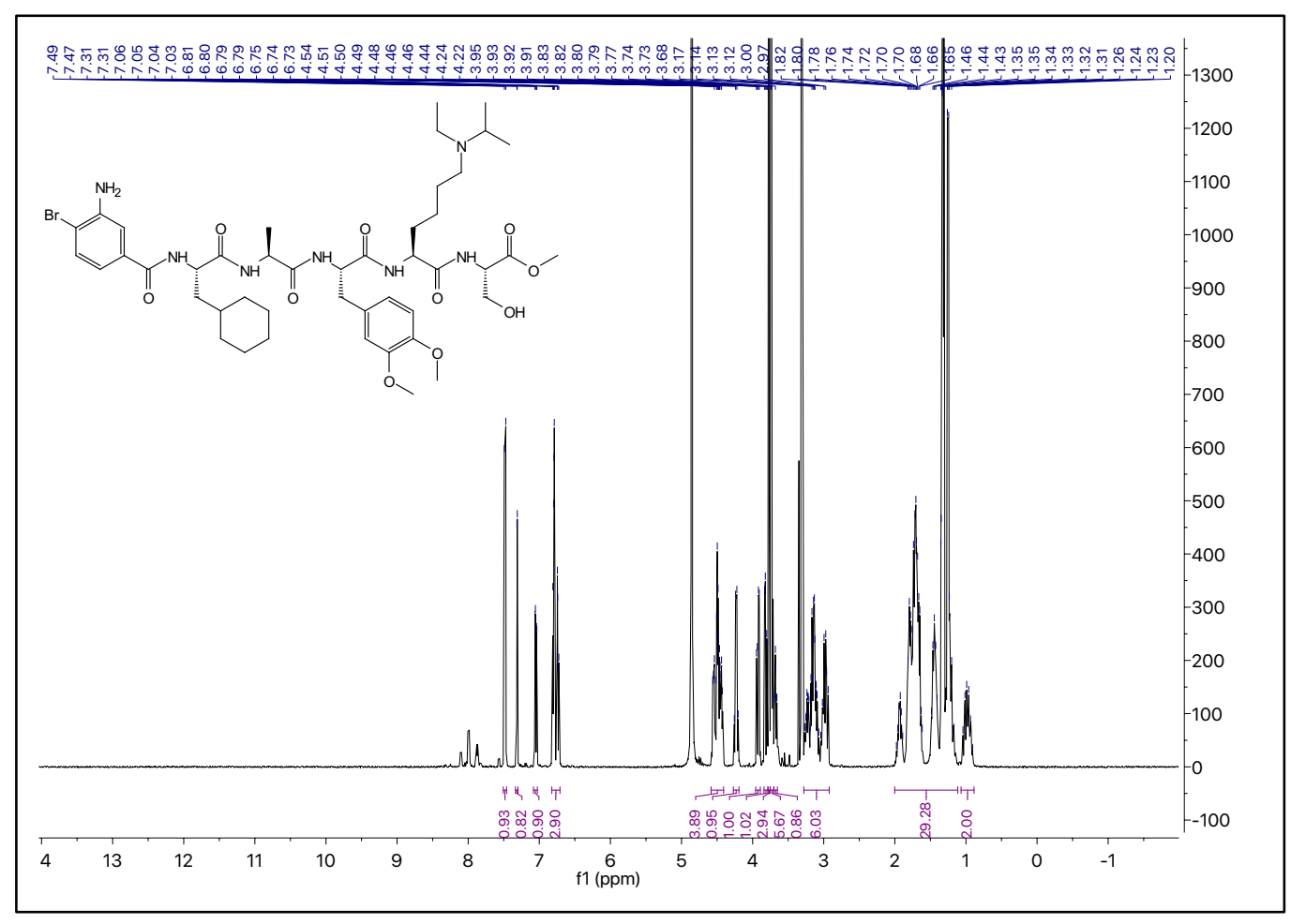

\section{UNC7564}




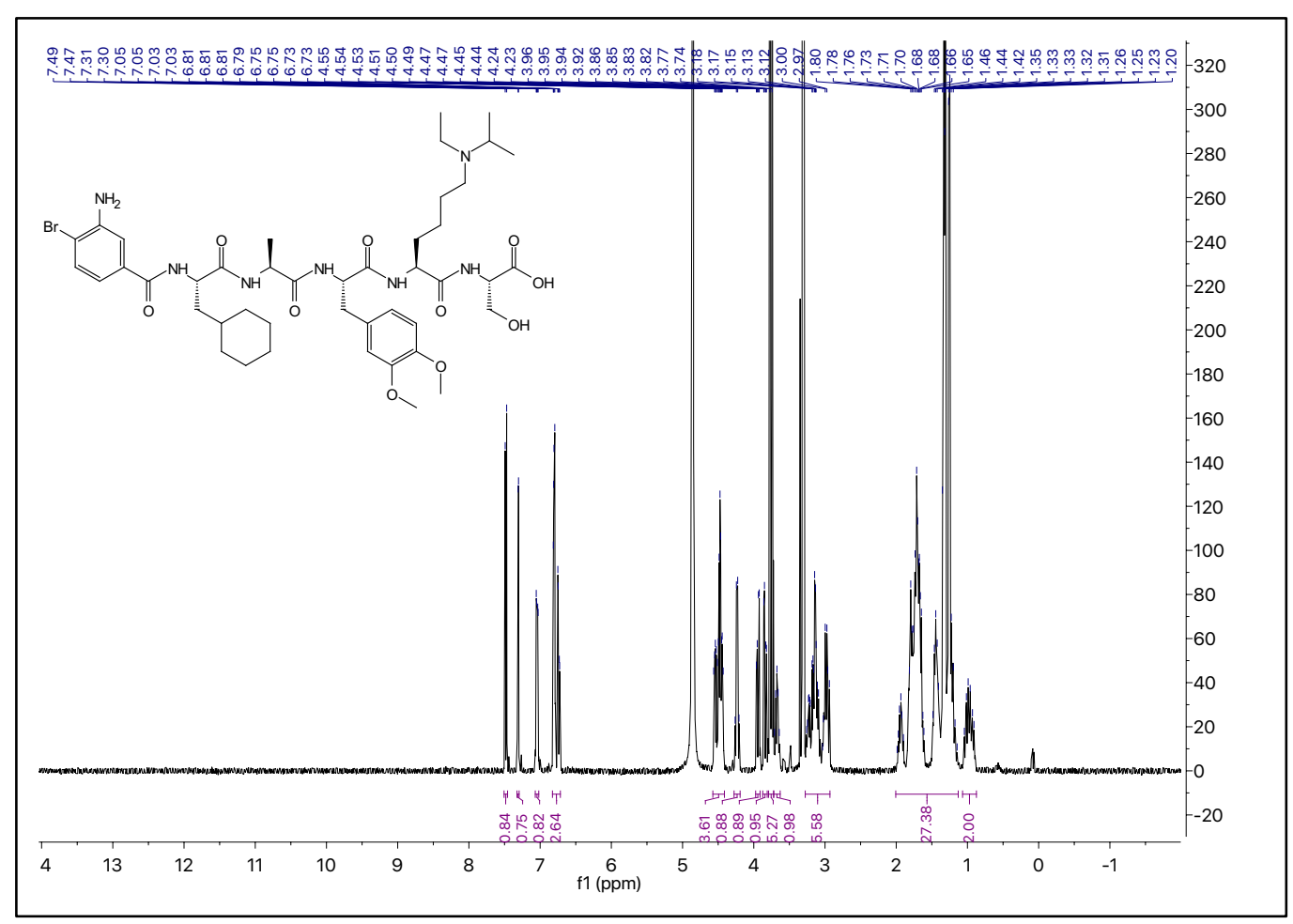

UNC7565

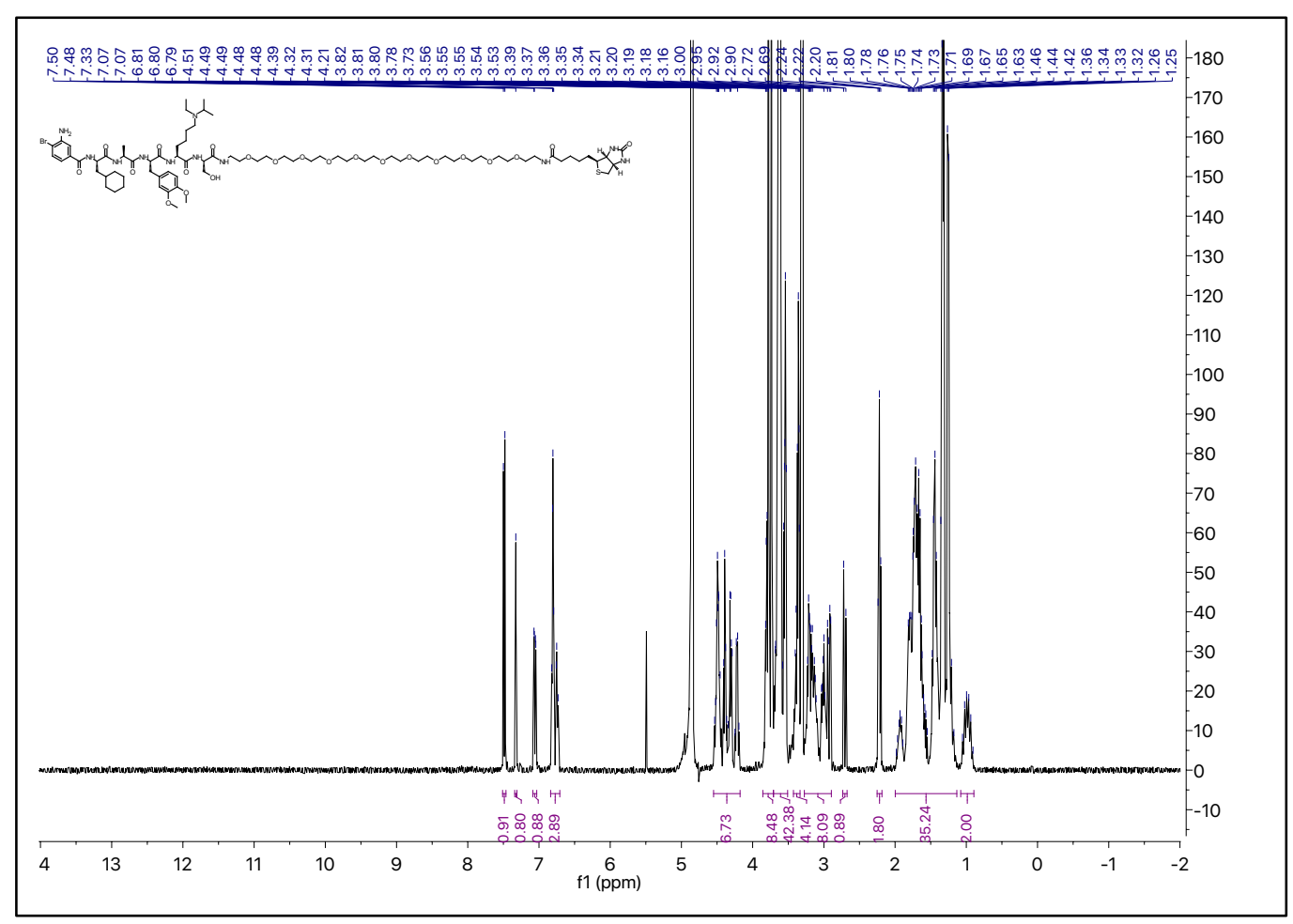

